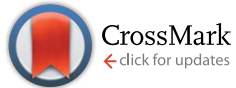

Cite this: RSC Adv., 2017, 7, 2494

Received 2nd November 2016 Accepted 2nd December 2016

DOI: $10.1039 / \mathrm{c} 6 \mathrm{ra} 26164 \mathrm{~g}$

www.rsc.org/advances

\section{Crystal structure, tunable luminescence and energy transfer properties of $\mathrm{Na}_{3} \mathrm{La}\left(\mathrm{PO}_{4}\right)_{2}: \mathrm{Tb}^{3+}, \mathrm{Eu}^{3+}$ phosphors $\dagger$}

\begin{abstract}
Dan Qin and Wanjun Tang*
A series of $\mathrm{Tb}^{3+}$ and/or $\mathrm{Eu}^{3+}$ doped $\mathrm{Na}_{3} \mathrm{La}\left(\mathrm{PO}_{4}\right)_{2}$ phosphors were successfully synthesized and their crystal structure and photoluminescence (PL) properties were investigated in detail. Double phosphates with the compositions $\mathrm{Na}_{3} \mathrm{~Tb}\left(\mathrm{PO}_{4}\right)_{2}$ and $\mathrm{Na}_{3} \mathrm{Eu}\left(\mathrm{PO}_{4}\right)_{2}$ were obtained by the substitution of Tb or Eu for La in the $\mathrm{Na}_{3} \mathrm{La}\left(\mathrm{PO}_{4}\right)_{2}$ host. XRD pattern analysis indicates that these obtained compounds crystallize in the orthorhombic system with the space group $P b c 2_{1}$. The crystal structure of the $\mathrm{Na}_{3} \mathrm{RE}\left(\mathrm{PO}_{4}\right)_{2}(\mathrm{RE}=\mathrm{Tb}, \mathrm{Eu})$ is made up of isolated $\mathrm{PO}_{4}$ tetrahedra and of sodium and $\mathrm{RE}$ atoms arranged in an ordered way. The $\mathrm{REO}_{y}$ polyhedra are isolated from one another, resulting in a high critical concentration of $\mathrm{Tb}^{3+}$ or $\mathrm{Eu}^{3+}$ activators. Under excitation of near-ultraviolet (NUV) irradiation, $\mathrm{Tb}^{3+}$ doped $\mathrm{Na}_{3} \mathrm{La}\left(\mathrm{PO}_{4}\right)_{2}$ shows a bluegreenish emission with a predominant peak at $546 \mathrm{~nm}$, while the emission spectra of $\mathrm{Eu}^{3+}$-doped $\mathrm{Na}_{3} \mathrm{La}\left(\mathrm{PO}_{4}\right)_{2}$ exhibits a reddish orange emission due to the ${ }^{5} \mathrm{D}_{0} \rightarrow{ }^{7} \mathrm{~F}_{J}$ transitions of $\mathrm{Eu}^{3+}$ ions. The energy transfer from $\mathrm{Tb}^{3+}$ to $\mathrm{Eu}^{3+}$ in the $\mathrm{Na}_{3} \mathrm{La}\left(\mathrm{PO}_{4}\right)_{2}$ host is demonstrated by the luminescence spectra and fluorescence decay dynamics. Meanwhile, the emission color of $\mathrm{Na}_{3} \mathrm{La}\left(\mathrm{PO}_{4}\right)_{2}: \mathrm{Tb}^{3+}, \mathrm{Eu}^{3+}$ can be tuned from green to red through tuning the $\mathrm{Tb}^{3+} / \mathrm{Eu}^{3+}$ ratio. These results indicate that the $\mathrm{Na}_{3} \mathrm{La}\left(\mathrm{PO}_{4}\right)_{2}: \mathrm{Tb}^{3+}, \mathrm{Eu}^{3+}$ phosphor exhibits broadband NUV absorption and green-reddish orange tunable emission, which might serve as a down-converting phosphor for NUV light-emitting diodes.
\end{abstract}

\section{Introduction}

Rare earth (RE) ions play an irreplaceable role in the development of lighting and display fields due to their abundant emission colors based on $4 \mathrm{f}-4 \mathrm{f}$ or $5 \mathrm{~d}-4 \mathrm{f}$ transitions. ${ }^{1-3}$ Recently, $\mathrm{RE}^{3+}$ ion doped phosphors based on double phosphate hosts have drawn much attention because of their high luminous efficiency, low sintering temperature, high thermal and chemical stability, and low cost. ${ }^{4,5}$ Double phosphates of mono- and trivalent cations with the general formula $\mathrm{M}_{3}^{\mathrm{I}} \mathrm{N}^{\mathrm{III}}\left(\mathrm{PO}_{4}\right)_{2}\left(\mathrm{M}^{\mathrm{I}}=\right.$ $\mathrm{Na}, \mathrm{K} ; \mathrm{N}^{\mathrm{III}}=\mathrm{Y}, \mathrm{Sc}, \mathrm{In}, \mathrm{Fe}$, rare earth elements) have high thermal and chemical stability and their host absorption edge locates at a rather short wavelength (about 140-180 nm), ${ }^{6}$ making them excellent host materials for luminescent materials. $\mathrm{M}_{3}^{\mathrm{I}} \mathrm{N}^{\mathrm{III}}\left(\mathrm{PO}_{4}\right)_{2}$ compounds crystallize in a trigonal, orthorhombic or monoclinic structure, depending on the type of $\mathrm{M}^{\mathrm{I}}$ or $\mathrm{N}^{\mathrm{III}}$ cations. ${ }^{7}$ Among them, $\mathrm{Na}_{3} \mathrm{RE}\left(\mathrm{PO}_{4}\right)_{2}(\mathrm{RE}=\mathrm{La}-\mathrm{Tb})$ compounds crystallize orthorhombic with the glaserite-type

Hubei Key Laboratory for Catalysis and Material Science, College of Chemistry and Material Science, South-Central University for Nationalities, Wuhan 430074, P. R. China. E-mail: tangmailbox@126.com; Fax:+86-27-67842752; Tel: +86-27-67842752 $\dagger$ Electronic supplementary information (ESI) available: F-7000 instrumental parameters; Fig. S1 Rietveld refinement of the powder XRD pattern of $\mathrm{Na}_{3} \mathrm{~Tb}_{0.95} \mathrm{Eu}_{0.5}\left(\mathrm{PO}_{4}\right)_{2}$; Fig. S2 Rietveld refinement of the powder XRD pattern of $\mathrm{Na}_{3} \mathrm{~Tb}_{0.3} \mathrm{Eu}_{0.7}\left(\mathrm{PO}_{4}\right)_{2}$. See DOI: 10.1039/c6ra26164g structure. They are built up on isolated $\mathrm{REO}_{y}$ polyhedral and $\mathrm{PO}_{4}$ tetrahedra. ${ }^{8}$ The presence of this particular structure suggests that the lattice can accommodate other cations with similar radii and charges without significant changes to the structural frame. ${ }^{9}$ Furthermore, this structure can weaken the concentration quenching effect and the critical concentration of activator ions is much higher than that of conventional inorganic phosphors. Therefore, the structure and optical properties of $\mathrm{Na}_{3} \mathrm{RE}\left(\mathrm{PO}_{4}\right)_{2}$-related phosphors have been extensively studied. A great number of glaserite-type phosphors, such as $\mathrm{Na}_{3} \mathrm{Y}\left(\mathrm{PO}_{4}\right)_{2}: \mathrm{Ce}^{3+},{ }^{10} \mathrm{Na}_{3} \mathrm{La}\left(\mathrm{PO}_{4}\right)_{2}: \mathrm{Er}^{3+},{ }^{11} \mathrm{Na}_{3} \mathrm{Gd}\left(\mathrm{PO}_{4}\right)_{2}: \mathrm{Ce}^{3+},{ }^{12}$ and $\mathrm{Na}_{3} \mathrm{RE}\left(\mathrm{PO}_{4}\right)_{2}: \mathrm{Yb}^{3+}(\mathrm{RE}=\mathrm{Y}, \mathrm{La}, \mathrm{Gd})^{\mathbf{1 3}}$ have been reported. Meanwhile, most of the phosphors are single-colored, and combining different phosphors is applied when a multicolor emission is needed. However, this combination suffers from the disadvantages of reabsorption among phosphors and different degradation rates. ${ }^{\mathbf{1 4}}$ Therefore, great efforts have been devoted to develop single-host phosphors with a multicolor emission to meet the increasing demand of different illumination applications. In order to achieve color tunable emitting in single-phase hosts, several strategies are used, including controlling the temperature, ${ }^{\mathbf{1 5}}$ band-gap modulation, ${ }^{\mathbf{1 6}}$ crystal field adjustment, ${ }^{17}$ the combination of multiple rare ions with various color emissions, ${ }^{18}$ and codoping ion pairs based on the energy transfer mechanism. Codoping different rare earth ions as sensitizers and activators in a single matrix is one of the most 
popular methods to control the emission color via energy transfer processes. ${ }^{19}$ Additional, tunable multicolor emission can be realized in phosphors under a single excitation wavelength. The multicolor tuning of phosphors has been achieved by co-doping $\mathrm{RE}^{3+}$ ion into suitable host lattice, such as $\mathrm{Eu}^{3+}$ $\mathrm{Bi}^{3+},{ }^{20} \mathrm{Tm}^{3+}-\mathrm{Dy}^{3+}$ (ref. 21) and $\mathrm{Tb}^{3+}-\mathrm{Eu}^{3+} .{ }^{22-24}$

It has been reported that $\mathrm{Na}_{3} \mathrm{La}\left(\mathrm{PO}_{4}\right)_{2}$ crystallizes in the orthorhombic structure. ${ }^{8} \mathrm{Eu}^{3+}$ and $\mathrm{Tb}^{3+}$ ions are frequently used as red and green activators in luminescent materials. ${ }^{19}$ However, the luminescence properties of $\mathrm{Tb}^{3+}$ and/or $\mathrm{Eu}^{3+}$ ions in $\mathrm{Na}_{3} \mathrm{La}\left(\mathrm{PO}_{4}\right)_{2}$ host under near ultraviolet (NUV) light excitation have not been reported, and so far the energy transfer phenomenon from $\mathrm{Tb}^{3+}$ to $\mathrm{Eu}^{3+}$. In this contribution, $\mathrm{Na}_{3}$ $\mathrm{La}\left(\mathrm{PO}_{4}\right)_{2}$ was chosen as the host material. The structure, luminescence properties and chromaticity stability of $\mathrm{Tb}^{3+}$ and/or $\mathrm{Eu}^{3+}$ activated $\mathrm{Na}_{3} \mathrm{La}\left(\mathrm{PO}_{4}\right)_{2}$ samples are studied in detail. The energy transfer process between $\mathrm{Tb}^{3+}$ and $\mathrm{Eu}^{3+}$ ions as well as the potential luminescence mechanism has been analyzed in $\mathrm{Na}_{3} \mathrm{La}\left(\mathrm{PO}_{4}\right)_{2}$ host upon the excitation wavelength of $378 \mathrm{~nm}$ irradiation.

\section{Experimental}

Powder samples of $\mathrm{Na}_{3} \mathrm{La}_{1-x}\left(\mathrm{PO}_{4}\right)_{2}: x \mathrm{Eu}^{3+}(x=0-1.0), \mathrm{Na}_{3}-$ $\mathrm{La}_{1-y}\left(\mathrm{PO}_{4}\right)_{2}: y \mathrm{~Tb}^{3+}(y=0-1.0), \mathrm{Na}_{3} \mathrm{La}_{0.7-x} \mathrm{~Tb}_{0.3}\left(\mathrm{PO}_{4}\right)_{2}: x \mathrm{Eu}^{3+}(x=$ $0-0.7)$, and $\mathrm{Na}_{3} \mathrm{La}_{0.95-y} \mathrm{Eu}_{0.05}\left(\mathrm{PO}_{4}\right)_{2}: y \mathrm{~Tb}^{3+}(y=0-0.95)$ were prepared as follows. Stoichiometric amounts of analytical reagents $\mathrm{NaNO}_{3}, \mathrm{NH}_{4} \mathrm{H}_{2} \mathrm{PO}_{4}$, and $99.99 \%$ pure $\mathrm{La}_{2} \mathrm{O}_{3}$ were mixed. An appropriate amount of $\mathrm{CO}\left(\mathrm{NH}_{2}\right)_{2}$ was added as fuel. 99.99\% pure $\mathrm{Eu}_{2} \mathrm{O}_{3}$ and $\mathrm{Tb}_{4} \mathrm{O}_{7}$ were dissolved in $\mathrm{HNO}_{3}$ to convert into nitrate completely. These reagents were dissolved in water and then introduced into a muffle furnace maintained at $600{ }^{\circ} \mathrm{C}$ for $5 \mathrm{~min}$. The obtained processor was subsequently ground in an agate mortar and then reacted at $900{ }^{\circ} \mathrm{C}$ for $4 \mathrm{~h}$ in air atmosphere. Finally, the products were gradually cooled to room temperature and reground for further measurements.

The phase purity of the products was checked by powder Xray diffraction (XRD) using a Bruker D8 X-ray diffractometer (Bruker Co. Ltd., Karlsruhe, Germany) with $\mathrm{Cu} K \alpha$ radiation $(\lambda=$ $1.5406 \AA$ ), operating at $40 \mathrm{kV}$ and $40 \mathrm{~mA}$. Structure refinements of XRD data were performed using the computer software General Structure Analysis System (GSAS) program. ${ }^{25}$ The luminescence emission and excitation spectra of the samples were measured on a fluorescence spectrophotometer (F-7000, Hitachi, Japan) equipped with a $150 \mathrm{~W}$ Xe light source. The luminescence decay data were collected on an Edinburgh FLS920 combined fluorescence lifetime and steady state spectrometer with a $450 \mathrm{~W}$ xenon lamp and $60 \mu \mathrm{F}$ flash lamp. For comparison, all measurements were conducted at room temperature with the identical instrumental parameters.

\section{Results and discussion}

\section{Phase identification and crystal structure}

The XRD patterns of $\mathrm{Tb}^{3+}$ and/or $\mathrm{Eu}^{3+}$ doped $\mathrm{Na}_{3} \mathrm{La}\left(\mathrm{PO}_{4}\right)_{2}$ samples were measured at room temperature. Fig. 1 shows the powder XRD profiles of some representative samples. No
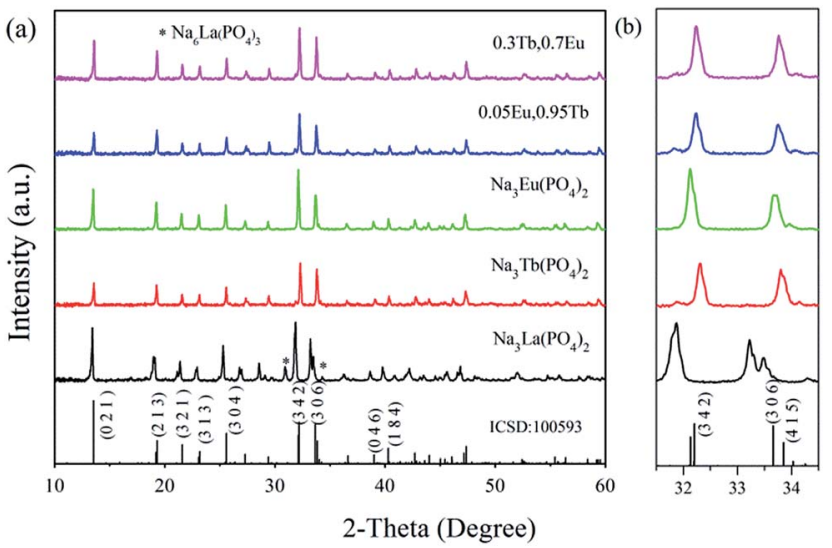

Fig. 1 Representative XRD patterns of $\mathrm{Na}_{3} \mathrm{RE}\left(\mathrm{PO}_{4}\right)_{2}(\mathrm{RE}=\mathrm{La}, \mathrm{Tb}, \mathrm{Eu})$ samples and ICSD no. 100593 (a); magnified XRD patterns in the region from 31.5 to $34.5 \mathrm{deg}(\mathrm{b})$.

records of $\mathrm{Na}_{3} \mathrm{La}\left(\mathrm{PO}_{4}\right)_{2}, \mathrm{Na}_{3} \mathrm{~Tb}\left(\mathrm{PO}_{4}\right)_{2}$ and $\mathrm{Na}_{3} \mathrm{Eu}\left(\mathrm{PO}_{4}\right)_{2}$ are available in Joint Committee on Powder Diffraction Standards (JCPDS) or Inorganic Crystal Structure Database (ICSD). As shown in Table 1, the radius $\mathrm{Nd}^{3+}$ is quite close to that of $\mathrm{La}^{3+}$, $\mathrm{Eu}^{3+}$ and $\mathrm{Tb}^{3+} .{ }^{26}$ The compound $\mathrm{Na}_{3} \mathrm{Nd}\left(\mathrm{PO}_{4}\right)_{2}$ is isostructural with $\mathrm{Na}_{3} \mathrm{RE}\left(\mathrm{PO}_{4}\right)_{2}(\mathrm{RE}=\mathrm{La}, \mathrm{Eu}$ and $\mathrm{Tb})$. Therefore, the standard data of $\mathrm{Na}_{3} \mathrm{Nd}\left(\mathrm{PO}_{4}\right)_{2}$ (ICSD no. 100593) serve as a certified reference. ${ }^{27}$ As presented in Fig. 1a, most of the samples are consistent with the standard file of $\mathrm{Na}_{3} \mathrm{Nd}\left(\mathrm{PO}_{4}\right)_{2}$, indicating that the obtained samples are single phase and heavily doping $\mathrm{Tb}$ and/or $\mathrm{Eu}$ ions do not change the crystal structure. This is attributed to that $\mathrm{Tb}^{3+}$ or $\mathrm{Eu}^{3+}$ occupies $\mathrm{La}^{3+}$ sites for their similar radii and identical valence. However, as an exceptional case, two additional weak diffraction peaks at $30.95^{\circ}$ and $34.27^{\circ}$ ascribed to $\mathrm{Na}_{6} \mathrm{La}\left(\mathrm{PO}_{4}\right)_{3}$ as a second phase can be discerned for the $\mathrm{Na}_{3} \mathrm{La}\left(\mathrm{PO}_{4}\right)_{2}$ sample. A small shift of the XRD peaks of the $\mathrm{Na}_{3} \mathrm{RE}\left(\mathrm{PO}_{4}\right)_{2}(\mathrm{RE}=\mathrm{La}, \mathrm{Eu}, \mathrm{Tb})$ samples in comparison to the standard data of $\mathrm{Na}_{3} \mathrm{Nd}\left(\mathrm{PO}_{4}\right)_{2}$ can be observed in Fig. 1b. The characteristic peak ( $\left.\begin{array}{ll}3 & 4\end{array}\right)$ shifts to the higher angle as the $\mathrm{RE}^{3+}$ sites are substituted by the $\mathrm{La}^{3+} \rightarrow \mathrm{Nd}^{3+} \rightarrow \mathrm{Eu}^{3+} \rightarrow \mathrm{Tb}^{3+}$ with the decrease of ionic radii. According to Bragg's diffraction equation, $2 d \sin \theta=n \lambda$, in which $n$ is an integer, $\lambda$ is the X-ray wavelength, $d$ is the spacing between the planes in the atomic lattice, and $\theta$ is the angle between the incident ray and the scattering planes. The substitution of the $\mathrm{La}^{3+}$ ions in the crystallographic structure by the smaller $\mathrm{Tb}^{3+}$ or $\mathrm{Eu}^{3+}$ ions reduces the cell dimensions of the crystal, leading to the increase of the $2 \theta$ value.

Table 1 The effective ionic radii of the different coordination sites of $\mathrm{RE}^{3+}$ in $\mathrm{REO}_{y}(\mathrm{RE}=\mathrm{La}, \mathrm{Nd}, \mathrm{Eu}, \mathrm{Tb} ; y=6,7,8)$

Ionic radius $(\AA)$

\begin{tabular}{lllll}
$y$ & $\mathrm{La}^{3+}$ & $\mathrm{Nd}^{3+}$ & $\mathrm{Eu}^{3+}$ & $\mathrm{Tb}^{3+}$ \\
\hline 6 & 1.032 & 0.983 & 0.947 & 0.923 \\
7 & 1.10 & - & 1.01 & 0.98 \\
8 & 1.16 & 1.109 & 1.066 & 1.04
\end{tabular}


Reported by Salmon et al. ${ }^{27} \mathrm{Na}_{3} \mathrm{Nd}\left(\mathrm{PO}_{4}\right)_{2}$ crystallizes in $P b c 2_{1}$ (no. 29) space group and orthorhombic crystal system (ICSD no. 100593). As shown in Fig. 1 , solid solutions of $\mathrm{Na}_{3} \mathrm{RE}\left(\mathrm{PO}_{4}\right)_{2}(\mathrm{RE}$ $=\mathrm{La}$, Eu and/or $\mathrm{Tb}$ ) may exist due the same valence and similar radii of these ions. ${ }^{28}$ Meanwhile, there are a lot of evidence about the iso-structural of orthorhombic $\mathrm{Na}_{3} \mathrm{Nd}\left(\mathrm{PO}_{4}\right)_{2}$ with other sodium and rare-earth double orthophosphates $\mathrm{Na}_{3}$ $\mathrm{RE}\left(\mathrm{PO}_{4}\right)_{2}(\mathrm{RE}=\mathrm{Y}, \mathrm{La}-\mathrm{Er}) .^{10,12,29,30}$ Here the crystal structure data of $\mathrm{Na}_{3} \mathrm{Nd}\left(\mathrm{PO}_{4}\right)_{2}$ is used as a starting model to refine the crystal structure. Fig. $2 \mathrm{a}$ and $\mathrm{b}$ exhibit the experimental, calculated and difference results from the Rietveld refinement of the two end components $\mathrm{Na}_{3} \mathrm{~Tb}\left(\mathrm{PO}_{4}\right)_{2}$ and $\mathrm{Na}_{3} \mathrm{Eu}\left(\mathrm{PO}_{4}\right)_{2}$, respectively. All of the observed peaks can be indexed to the corresponding data. We can conclude that the desired single-phase phosphors with a glaserite-type structure have been synthesized and the patterns have not changed by doping $\mathrm{Tb}^{3+}$ and/or $\mathrm{Eu}^{3+}$ ions. No other phase or impurity can be detected, confirming the formation of a single phase. The low values of $R_{\mathrm{wp}}, R_{\mathrm{p}}$ and $\chi^{2}$ shown in Table 2 indicate that the refined crystal structure data are reliable. Both $\mathrm{Na}_{3} \mathrm{~Tb}\left(\mathrm{PO}_{4}\right)_{2}$ and $\mathrm{Na}_{3} \mathrm{Eu}\left(\mathrm{PO}_{4}\right)_{2}$ crystallize in the orthorhombic crystal system with space group $P b c 2_{1}$ and $N$ $=24$. Their unit cell parameters differ from that of $\mathrm{Na}_{3} \mathrm{Nd}\left(\mathrm{PO}_{4}\right)_{2}$ $\left(a=15.874 \AA, b=13.952 \AA, c=18.470 \AA, V=4090.63 \AA^{3}\right)$, resulted from the substitution of $\mathrm{Nd}^{3+}$ by $\mathrm{Tb}^{3+}$ or $\mathrm{Eu}^{3+}$. The Rietveld analysis shows that the samples are in crystalline phase
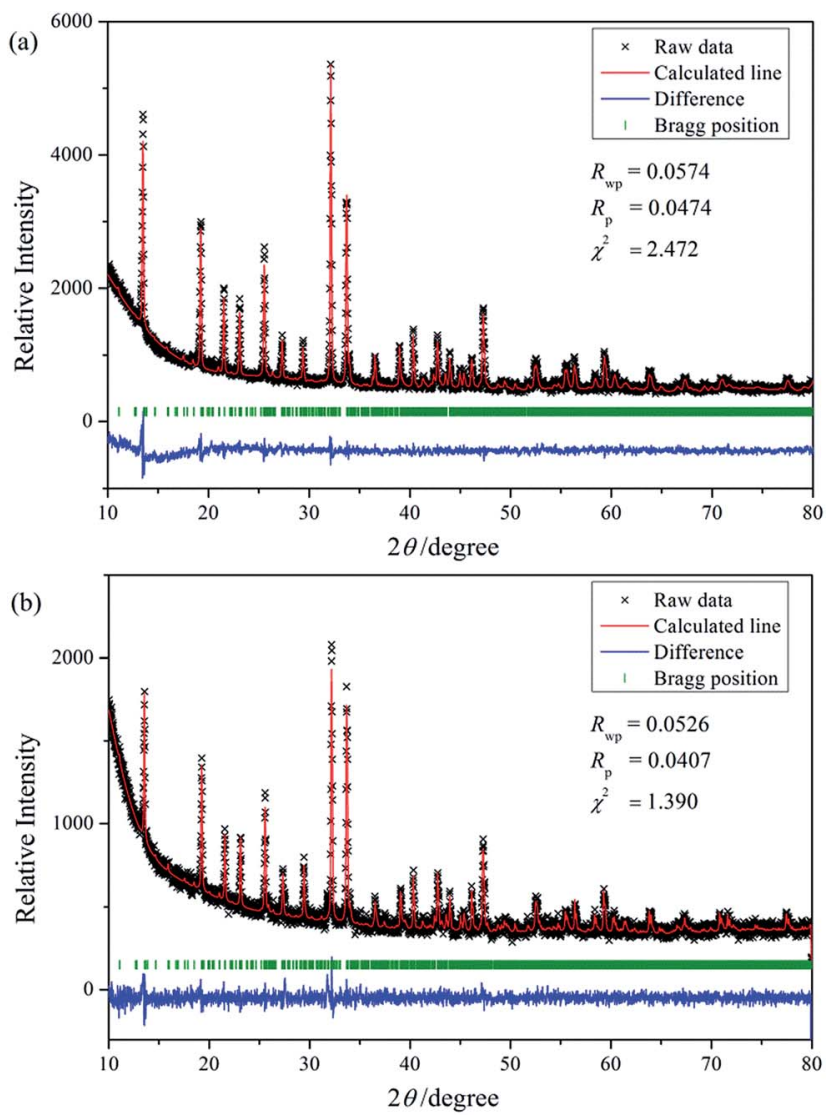

Fig. 2 Rietveld analysis patterns for $\mathrm{X}$-ray powder diffraction data of $\mathrm{Na}_{3} \mathrm{~Tb}\left(\mathrm{PO}_{4}\right)_{2}$ (a) and $\mathrm{Na}_{3} \mathrm{Eu}\left(\mathrm{PO}_{4}\right)_{2}$ (b) compounds.
Table 2 Crystallographic data and details in the data collection and refinement parameters for $\mathrm{Na}_{3} \mathrm{RE}\left(\mathrm{PO}_{4}\right)_{2}(\mathrm{RE}=\mathrm{Eu}$ and $\mathrm{Tb})$

\begin{tabular}{lll}
\hline Sample & $\mathrm{Na}_{3} \mathrm{~Tb}\left(\mathrm{PO}_{4}\right)_{2}$ & $\mathrm{Na}_{3} \mathrm{Eu}\left(\mathrm{PO}_{4}\right)_{2}$ \\
\hline Space group & $P b c 2_{1}$ & $P b c 2_{1}$ \\
Symmetry & Orthorhombic & Orthorhombic \\
$a / \AA$ & 15.899 & 15.920 \\
$b / \AA$ & 13.950 & 13.936 \\
$c / \AA$ & 18.405 & 18.425 \\
$V / \AA^{3}$ & 4082.1 & 4087.8 \\
$\alpha=\beta=\gamma, \mathrm{deg}$ & 90 & 90 \\
$R_{\mathrm{wp}}, \%$ & 5.74 & 5.26 \\
$R_{\mathrm{p}}, \%$ & 4.74 & 4.07 \\
$\chi^{2}$ & 2.472 & 1.390 \\
\end{tabular}

and no phase mixture was observed. Rietveld plots of $\mathrm{Na}_{3}$ $\mathrm{Tb}_{0.95} \mathrm{Eu}_{0.5}\left(\mathrm{PO}_{4}\right)_{2}$ and $\mathrm{Na}_{3} \mathrm{~Tb}_{0.3} \mathrm{Eu}_{0.7}\left(\mathrm{PO}_{4}\right)_{2}$ are presented in Fig. S1 and S2 (in the ESI $†$ ), respectively. All of the observed peaks satisfy the reflection conditions, confirming the formation of a single phase with no impurities. The remarkable good fit between the experimental data and calculated line confirm the phase purity of the as-prepared samples.

Fig. 3 a depicts the crystal structure of the $\mathrm{Na}_{3} \mathrm{RE}\left(\mathrm{PO}_{4}\right)_{2}(\mathrm{RE}=$ $\mathrm{La}, \mathrm{Eu}, \mathrm{Tb}$ ) unit cell viewed along $a$-direction from the parallel projection, the coordination environment of $\mathrm{RE}^{3+}$ sites, and the ideal glaserite structure. The $\mathrm{Na}_{3} \mathrm{RE}\left(\mathrm{PO}_{4}\right)_{2}$ framework is made up of isolated $\mathrm{PO}_{4}$ tetrahedron and $\left[\mathrm{REO}_{y}\right](y=6,7,8)$ polyhedron that arranged in an ordered way which results in the tunnel. The basic structure units are helical ribbons $\left[\mathrm{REO}_{y}\right]$ formed by six corner sharing $\left[\mathrm{PO}_{4}\right]$ tetrahedron that alternate "up" and "down.". The pinwheels are linked through $\left[\mathrm{PO}_{4}\right]$ tetrahedra to form layers with alkali atoms located between the layers. Fig. $3 \mathrm{~b}$ and $\mathrm{c}$ demonstrate the six kinds of RE sites in a unit cell along $b$-direction. The ribbons run along some

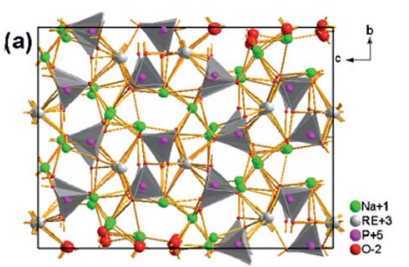

(c) , $\rightarrow$
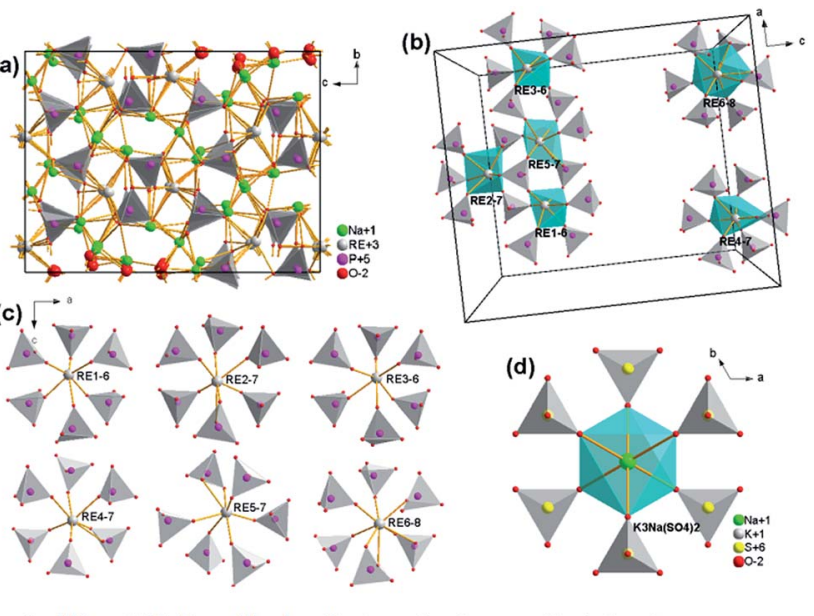

six different RE sites with glaserite-type structure

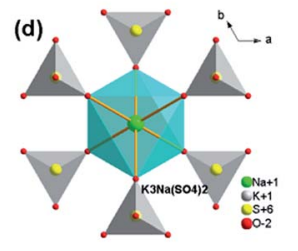

Fig. 3 Crystal structure of the $\mathrm{Na}_{3} \mathrm{RE}\left(\mathrm{PO}_{4}\right)_{2}(\mathrm{RE}=\mathrm{La}, \mathrm{Eu}, \mathrm{Tb})$ unit cell viewed along a-direction from the parallel projection (a); the coordination environment of different $\mathrm{Nd}^{3+}$ sites in a unit cell (b); the expansion particular six kinds of $\mathrm{Nd}^{3+}$ (c); the ideal glaserite structure of the $\mathrm{K}_{3} \mathrm{Na}\left(\mathrm{SO}_{4}\right)_{2}$ (d). 
directions of unit-cell with a period of four or eight tetrahedral. The coordination of the RE atoms is 6-folded for RE1 and RE3, 7-folded for RE2, RE4, RE5 and 8-folded for RE6. The variety in coordination numbers is due to a rotation of the certain $\left[\mathrm{PO}_{4}\right]$ tetrahedron around one of their edges. The $\mathrm{REO}_{y}$ polyhedral are isolated because they do not share any $\mathrm{O}$ atom. In addition, the shortest RE-RE distances in $\mathrm{Na}_{3} \mathrm{~Tb}\left(\mathrm{PO}_{4}\right)_{2}$ and $\mathrm{Na}_{3} \mathrm{Eu}\left(\mathrm{PO}_{4}\right)_{2}$ are about 4.641 and $4.646 \AA$ (RE2-RE5), respectively, which is a long distance that energy migration of the doped rare earth ions is difficult, similar observation has also been witnessed in some systems such as $\mathrm{Na}_{3} \mathrm{Gd}_{1-x} \mathrm{Eu}_{x}\left(\mathrm{PO}_{4}\right)_{2}$ (ref. 31) and $\mathrm{Na}_{3} \mathrm{Gd}\left(\mathrm{PO}_{4}\right)_{2}: \mathrm{Ce}^{3+} \cdot{ }^{12}$

\section{Luminescence properties of $\mathrm{Tb}^{3+}$ and/or $\mathrm{Eu}^{3+}$ doped $\mathrm{Na}_{3} \mathrm{La}\left(\mathrm{PO}_{4}\right)_{2}$ phosphors}

Fig. 4 illustrates the UV-vis excitation (PLE, $\lambda_{\mathrm{em}}=546 \mathrm{~nm}$ ) and emission (PL, $\lambda_{\mathrm{em}}=378 \mathrm{~nm}$ ) spectra of $\mathrm{Na}_{3} \mathrm{La}_{1-x}\left(\mathrm{PO}_{4}\right)_{2}: \mathrm{TTb}^{3+}$ with $x=0.01-1.0$. The PLE spectrum of $\mathrm{Na}_{3} \mathrm{~Tb}\left(\mathrm{PO}_{4}\right)_{2}$ involves several sharp lines in the $280-420 \mathrm{~nm}$ range. The sharp $\mathrm{f}-\mathrm{f}$ excitation lines at about 302, 317, 340, 351, 358, 368, 378 and $486 \mathrm{~nm}$ are assigned to ${ }^{7} \mathrm{~F}_{6}{ }^{5} \mathrm{H}_{6},{ }^{7} \mathrm{~F}_{6}-{ }^{5} \mathrm{H}_{7},{ }^{7} \mathrm{~F}_{6}-{ }^{5} \mathrm{G}_{2},{ }^{7} \mathrm{~F}_{6}-{ }^{5} \mathrm{D}_{2}$, ${ }^{7} \mathrm{~F}_{6}-{ }^{5} \mathrm{~L}_{10},{ }^{7} \mathrm{~F}_{6}{ }^{-5} \mathrm{G}_{6}$ and ${ }^{7} \mathrm{~F}_{6}{ }^{-5} \mathrm{D}_{4}$, respectively. ${ }^{31}$ Under $378 \mathrm{~nm}$ NUV excitation, the PL spectrum of $\mathrm{Na}_{3} \mathrm{La}_{0.99}\left(\mathrm{PO}_{4}\right)_{2}: 0.01 \mathrm{~Tb}^{3+}$ presents a group of ${ }^{5} \mathrm{D}_{3,4} \rightarrow{ }^{7} \mathrm{~F}_{J}$ transitions: ${ }^{5} \mathrm{D}_{3} \rightarrow{ }^{7} \mathrm{~F}_{5}(415 \mathrm{~nm})$, ${ }^{5} \mathrm{D}_{3} \rightarrow{ }^{7} \mathrm{~F}_{4}(437 \mathrm{~nm}),{ }^{5} \mathrm{D}_{4} \rightarrow{ }^{7} \mathrm{~F}_{6}(490 \mathrm{~nm}),{ }^{5} \mathrm{D}_{4} \rightarrow{ }^{7} \mathrm{~F}_{5}(546 \mathrm{~nm})$, ${ }^{5} \mathrm{D}_{4} \rightarrow{ }^{7} \mathrm{~F}_{4}(586 \mathrm{~nm})$ and ${ }^{5} \mathrm{D}_{4} \rightarrow{ }^{7} \mathrm{~F}_{3}(623 \mathrm{~nm})$. With the increase of $\mathrm{Tb}^{3+}$ concentration $(x)$, the blue emissions from the ${ }^{5} \mathrm{D}_{3} \rightarrow$ ${ }^{7} \mathrm{~F}_{5,4}$ transitions are quenched gradually, while the green emissions from the ${ }^{5} \mathrm{D}_{4} \rightarrow{ }^{7} \mathrm{~F}_{6,5,4,3}$ transitions increase continuously. For the $\mathrm{Tb}^{3+}$ ion, the energy gap between the ${ }^{5} \mathrm{D}_{3}$ and ${ }^{5} \mathrm{D}_{4}$ levels is about $5915 \mathrm{~cm}^{-1}$, which is quite close to that between ${ }^{7} \mathrm{~F}_{6}$ and ${ }^{7} \mathrm{~F}_{0}$ levels $\left(6000 \mathrm{~cm}^{-1}\right) \cdot{ }^{32}$ Hence, if the $\mathrm{Tb}^{3+}$ concentration $(y)$ is high enough, the emission from the ${ }^{5} \mathrm{D}_{3}$ level of $\mathrm{Tb}^{3+}$ is much weaker than that from the ${ }^{5} \mathrm{D}_{4}$ level due to the cross relaxation via the resonant energy transfer process: $\mathrm{Tb}^{3+}\left({ }^{5} \mathrm{D}_{3}\right)+$ $\mathrm{Tb}^{3+}\left({ }^{7} \mathrm{~F}_{6}\right) \rightarrow \mathrm{Tb}^{3+}\left({ }^{5} \mathrm{D}_{4}\right)+\mathrm{Tb}^{3+}\left({ }^{7} \mathrm{~F}_{0}\right)$ and the green emission of the ${ }^{5} \mathrm{D}_{4} \rightarrow{ }^{7} \mathrm{~F}_{5}(546 \mathrm{~nm})$ becomes predominant. ${ }^{33}$ The PL intensity of $\mathrm{Tb}^{3+}{ }^{5} \mathrm{D}_{4} \rightarrow{ }^{7} \mathrm{~F}_{5}$ transition increases gradually with

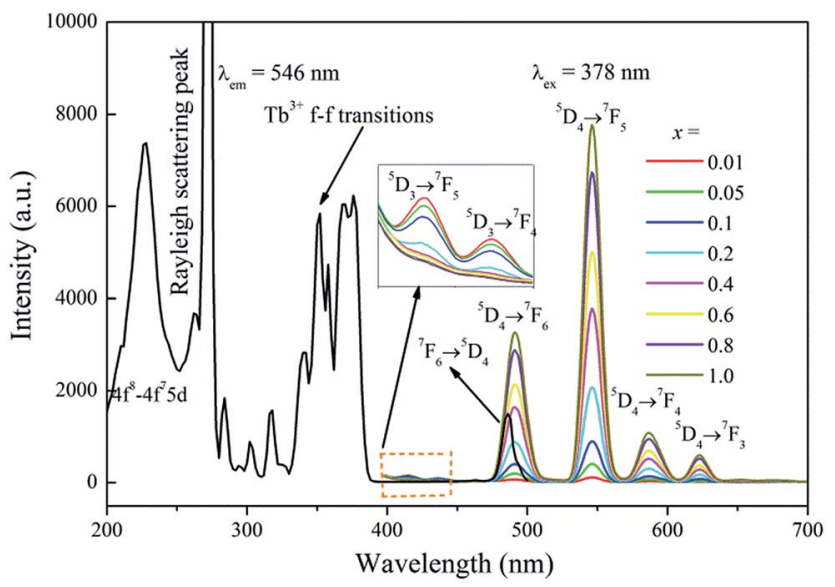

Fig. 4 The PLE spectrum of $\mathrm{Na}_{3} \mathrm{~Tb}\left(\mathrm{PO}_{4}\right)_{2}$ and the PL spectra of $\mathrm{Na}_{3}$ $\mathrm{La}_{1-x}\left(\mathrm{PO}_{4}\right)_{2}: x \mathrm{~Tb}^{3+}(x=0.01-1.0)$ samples. its concentration $(x)$ increasing, and reaches a maximum at $x=$ 1. This result indicates that no concentration quenching exists in the $\mathrm{Na}_{3} \mathrm{La}\left(\mathrm{PO}_{4}\right)_{2}$ host among the $\mathrm{Tb}^{3+}$ ions. The $\mathrm{Na}_{3} \mathrm{~Tb}\left(\mathrm{PO}_{4}\right)_{2}$ sample shows strong green emission under $378 \mathrm{~nm}$ NUV irradiation excitation, which makes it be a potential green phosphor for NUV LED application.

The PLE spectrum of $\mathrm{Na}_{3} \mathrm{Eu}\left(\mathrm{PO}_{4}\right)_{2}$ and PL spectra of $\mathrm{Na}_{3}-$ $\mathrm{La}_{1-y}\left(\mathrm{PO}_{4}\right)_{2}: y \mathrm{Eu}^{3+}(y=0.01-1.0)$ are shown in Fig. 5. The PLE spectrum consists of a weak broad band assigned to the chargetransfer transition (CTB) between $\mathrm{Eu}^{3+}$ and $\mathrm{O}^{2-}$, some narrow lines in the range of $230-320 \mathrm{~nm}$ (the strongest peak located at about $306 \mathrm{~nm}$ is due to Rayleigh scattering), and several sharp lines from $360-480 \mathrm{~nm}$. These sharp lines correspond to the characteristic $\mathrm{f} \rightarrow \mathrm{f}$ transitions of $\mathrm{Eu}^{3+}$ ions within its $4 \mathrm{f}^{6}$ configuration. They are ascribed to ${ }^{7} \mathrm{~F}_{0} \rightarrow{ }^{5} \mathrm{D}_{4}(360 \mathrm{~nm}),{ }^{7} \mathrm{~F}_{0} \rightarrow$ ${ }^{5} \mathrm{G}_{J},{ }^{5} \mathrm{~L}_{7}(381 \mathrm{~nm}),{ }^{7} \mathrm{~F}_{0} \rightarrow{ }^{5} \mathrm{~L}_{6}(394 \mathrm{~nm}),{ }^{7} \mathrm{~F}_{0} \rightarrow{ }^{5} \mathrm{D}_{3}(414 \mathrm{~nm})$, and ${ }^{7} \mathrm{~F}_{0} \rightarrow{ }^{5} \mathrm{D}_{2}(464 \mathrm{~nm})$ transitions of $\mathrm{Eu}^{3+}$ ion, respectively. Excitation into the ${ }^{7} \mathrm{~F}_{0} \rightarrow{ }^{5} \mathrm{~L}_{6}$ transition of $\mathrm{Eu}^{3+}$ at $394 \mathrm{~nm}$ yields some characteristic emission lines from the ${ }^{5} \mathrm{D}_{0,1}$ excited states to the ${ }^{7} \mathrm{~F}_{J}$ ground states, i.e., ${ }^{5} \mathrm{D}_{1} \rightarrow{ }^{7} \mathrm{~F}_{1}(536 \mathrm{~nm}),{ }^{5} \mathrm{D}_{1} \rightarrow{ }^{7} \mathrm{~F}_{2}(556$ $\mathrm{nm}),{ }^{5} \mathrm{D}_{0} \rightarrow{ }^{7} \mathrm{~F}_{1}(594 \mathrm{~nm}),{ }^{5} \mathrm{D}_{0} \rightarrow{ }^{7} \mathrm{~F}_{2}(620 \mathrm{~nm}),{ }^{5} \mathrm{D}_{0} \rightarrow{ }^{7} \mathrm{~F}_{3}(655$ $\mathrm{nm})$, and ${ }^{5} \mathrm{D}_{0} \rightarrow{ }^{7} \mathrm{~F}_{4}(703 \mathrm{~nm})$, respectively. ${ }^{34}$ However, the ${ }^{5} \mathrm{D}_{0}$ $\rightarrow{ }^{7} \mathrm{~F}_{0}$ transition (about $580 \mathrm{~nm}$ ) is very weak and can hardly be detected.

The two dominant bands at $594\left({ }^{5} \mathrm{D}_{0} \rightarrow{ }^{7} \mathrm{~F}_{1}\right.$ transition $)$ and $620 \mathrm{~nm}\left({ }^{5} \mathrm{D}_{0} \rightarrow{ }^{7} \mathrm{~F}_{2}\right.$ transition $)$ confer on the sample an orangered luminescence upon excitation with $394 \mathrm{~nm}$ light. It is known that the magnetic-dipole transition ${ }^{5} \mathrm{D}_{0} \rightarrow{ }^{7} \mathrm{~F}_{1}$ is insensitive to the symmetry of the $\mathrm{Eu}^{3+}$ site, while the forced electric dipole transition ${ }^{5} \mathrm{D}_{0} \rightarrow{ }^{7} \mathrm{~F}_{2}$ is hypersensitive to the local environment. ${ }^{35,36}$ Therefore, the intensity ratio $(R)$ of $\left({ }^{5} \mathrm{D}_{0} \rightarrow\right.$ $\left.{ }^{7} \mathrm{~F}_{2}\right) /\left({ }^{5} \mathrm{D}_{0} \rightarrow{ }^{7} \mathrm{~F}_{1}\right)$ gives a measure of the $\mathrm{Eu}^{3+}$ site symmetry in the lattice. A higher value of $R(R>1)$ suggests that $\mathrm{Eu}^{3+}$ locates at the site without inversion symmetry. Otherwise, $\mathrm{Eu}^{3+}$ ion locates at the site with inversion symmetry, leading to a lower value of $R(1>R>0) .{ }^{37}$ As shown in Fig. $3 \mathrm{~d}, \mathrm{Na}^{+}$has an inversion symmetric environment in the ideal glaserite structure of $\mathrm{K}_{3} \mathrm{Na}\left(\mathrm{SO}_{4}\right)_{2}$. However, upon substitution of $\mathrm{Na}^{+}$sites by $\mathrm{RE}^{3+}$,

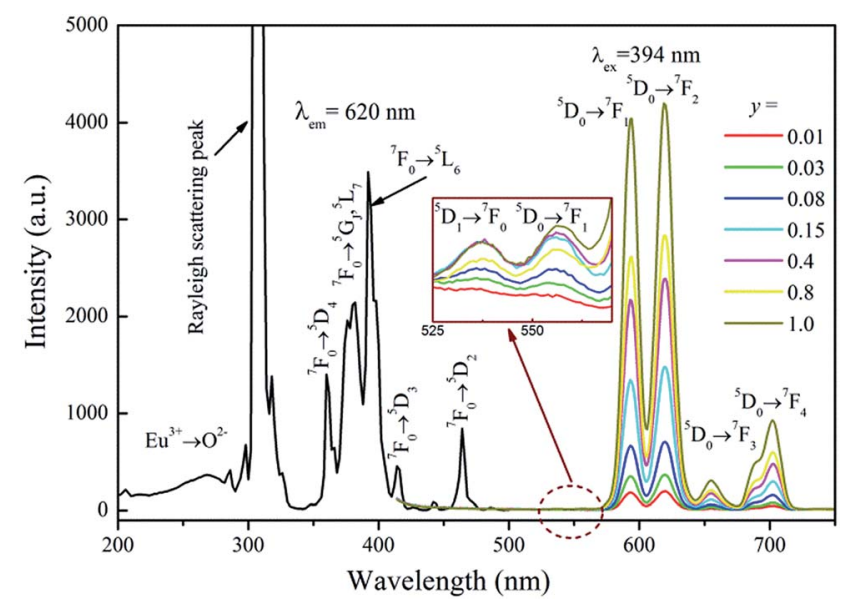

Fig. 5 The PLE spectrum of $\mathrm{Na}_{3} \mathrm{Eu}\left(\mathrm{PO}_{4}\right)_{2}$ and the PL spectra of $\mathrm{Na}_{3}-$ $\mathrm{La}_{1-y}\left(\mathrm{PO}_{4}\right)_{2}: \mathrm{Eu}^{3+}(y=0-1)$ samples. 
there will be some distortion in $\mathrm{NaO}_{6}$ octahedron. The $\mathrm{Na}_{3}$ $\mathrm{RE}\left(\mathrm{PO}_{4}\right)_{2}$ structure seems to be a distorted glaserite structure. In this structure six different types of $\mathrm{REO}_{y}$ polyhedral can be expected. Hence, the $\mathrm{Eu}^{3+}$ ion may occupy six sites in the $\mathrm{Na}_{3}$ $\mathrm{RE}\left(\mathrm{PO}_{4}\right)_{2}$ lattice, as shown in Fig. $3 \mathrm{~b}$ and c. Here, the intensity of ${ }^{5} \mathrm{D}_{0} \rightarrow{ }^{7} \mathrm{~F}_{1}$ is comparable with that of ${ }^{5} \mathrm{D}_{0} \rightarrow{ }^{7} \mathrm{~F}_{2}$. The value of $R$ calculated is about 1.02, indicating that the $\mathrm{Eu}^{3+}$ ions occupies a symmetric and a non-symmetric site almost equally. This agrees with the results of $\mathrm{Eu}^{3+}$ doped $\mathrm{K}_{3} \mathrm{Y}\left(\mathrm{PO}_{4}\right)_{2}$ (ref. 34) and $\mathrm{Na}_{3} \mathrm{Y}\left(\mathrm{PO}_{4}\right)_{2}$ (ref. 38) but challenges the results of $\mathrm{Eu}^{3+}$ doped $\mathrm{Rb}_{3} \mathrm{Y}_{2}\left(\mathrm{PO}_{4}\right)_{3}$ and $\mathrm{Rb}_{3} \mathrm{La}\left(\mathrm{PO}_{4}\right)_{2} \cdot{ }^{39}$

The PL intensity $\left({ }^{5} \mathrm{D}_{0} \rightarrow{ }^{7} \mathrm{~F}_{2}\right)$ of $\mathrm{Na}_{3} \mathrm{La}_{1-y}\left(\mathrm{PO}_{4}\right)_{2}: y \mathrm{Eu}^{3+}$ increases with increasing $\mathrm{Eu}^{3+}$ concentration $(y)$ until a maximum intensity about $y=1.0$ is reached. These observations confirm that the concentration quenching of $\mathrm{Eu}^{3+}$ does not occur in $\mathrm{Na}_{3} \mathrm{La}\left(\mathrm{PO}_{4}\right)_{2}$ host, so highly doping concentration samples are performed here.

It is worthy to be noted that both $\mathrm{Na}_{3} \mathrm{La}_{1-x}\left(\mathrm{PO}_{4}\right)_{2}: x \mathrm{~Tb}^{3+}$ and $\mathrm{Na}_{3} \mathrm{La}_{1-y}\left(\mathrm{PO}_{4}\right)_{2}: y \mathrm{Eu}^{3+}$ phosphors have a much high quenching concentration, actually the complete quenching would not occur even at $x$ or $y=1.0$, at which the $\mathrm{La}^{3+}$ sites are replaced by $\mathrm{Tb}^{3+}$ or $\mathrm{Eu}^{3+}$ completely. Taking into account the inherent structural feature of $\mathrm{Na}_{3} \mathrm{RE}\left(\mathrm{PO}_{4}\right)_{2}$ host, in which the $\mathrm{Tb}^{3+}$ or $\mathrm{Eu}^{3+}$ ions occupy the $\mathrm{RE}^{3+}$ sites of polyhedral which isolate from each other by a large spatial distance and join by RE-O-P-O-RE. The large spatial distance between $\mathrm{RE}^{3+}$ ions and the shielding of $\mathrm{PO}_{4}$ tetrahedrons hinders the long range energy transfer between $\mathrm{Tb}^{3+}$ or $\mathrm{Eu}^{3+}$ ions and consequently prevents the occurrence of concentration quenching. Therefore, the high concentration quenching was observed in $\mathrm{Na}_{3} \mathrm{La}_{1-x}\left(\mathrm{PO}_{4}\right)_{2}: x \mathrm{~Tb}^{3+}$ and $\mathrm{Na}_{3} \mathrm{La}_{1-y}\left(\mathrm{PO}_{4}\right)_{2}: y \mathrm{Eu}^{3+}$ phosphors. The similar phenomenon was also reported by Chen et al. in $\mathrm{K}_{3} \mathrm{R}\left(\mathrm{PO}_{4}\right)_{2}: \mathrm{Tb}^{3+}(\mathrm{R}=\mathrm{Y}$ and Gd) phosphors, ${ }^{40} \mathrm{Ju}$ et al. in $\mathrm{Na}_{3} \mathrm{Gd}_{1-x} \mathrm{Eu}_{x}\left(\mathrm{PO}_{4}\right)_{2}$ phosphors, ${ }^{30}$ and Jiang et al. in $\mathrm{K}_{3} \mathrm{Gd}\left(\mathrm{PO}_{4}\right)_{2}: \mathrm{Tb}^{3+}, \mathrm{Eu}^{3+}$ phosphor. ${ }^{41}$

In order to obtain multicolor tunable luminescence of the $\mathrm{Na}_{3} \mathrm{La}\left(\mathrm{PO}_{4}\right)_{2}$ phosphor, $\mathrm{Tb}^{3+}$ and $\mathrm{Eu}^{3+}$ ions with different relative concentration into the $\mathrm{Na}_{3} \mathrm{La}\left(\mathrm{PO}_{4}\right)_{2}$ host lattice were codoped in our work. The PLE and PL spectra of the

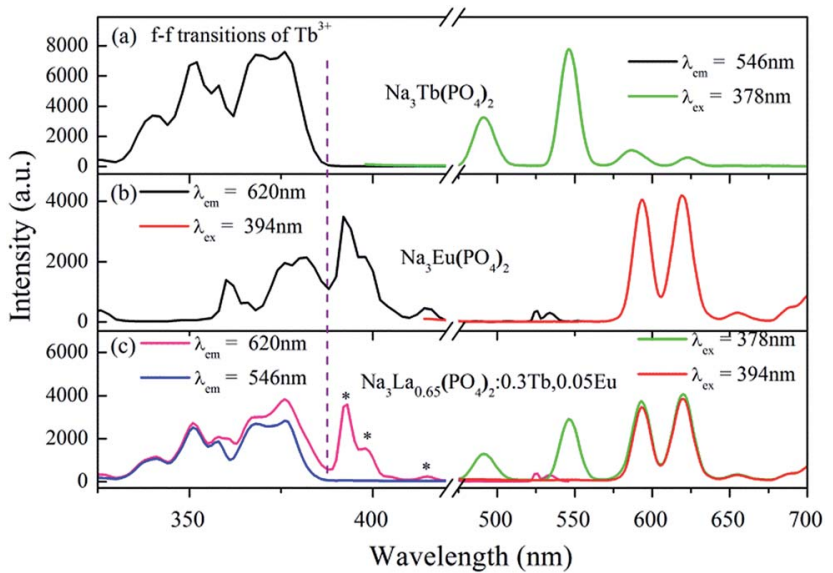

Fig. 6 PLE and PL spectra of $\mathrm{Na}_{3} \mathrm{~Tb}\left(\mathrm{PO}_{4}\right)_{2}$ (a), $\mathrm{Na}_{3} \mathrm{Eu}\left(\mathrm{PO}_{4}\right)_{2}$ (b), and $\mathrm{Na}_{3} \mathrm{La}_{0.65}\left(\mathrm{PO}_{4}\right)_{2}: 0.3 \mathrm{~Tb}^{3+}, 0.05 \mathrm{Eu}^{3+}$ (c).
$\mathrm{Na}_{3} \mathrm{La}_{0.65}\left(\mathrm{PO}_{4}\right)_{2}: 0.3 \mathrm{~Tb}^{3+}, 0.05 \mathrm{Eu}^{3+}$ sample are shown in Fig. 6. For comparison, the PLE and PL spectra of $\mathrm{Na}_{3} \mathrm{~Tb}\left(\mathrm{PO}_{4}\right)_{2}$ and $\mathrm{Na}_{3} \mathrm{Eu}\left(\mathrm{PO}_{4}\right)_{2}$ are also presented. The PLE spectrum (Fig. $6 \mathrm{c}$ ) of the $\mathrm{Na}_{3} \mathrm{La}_{0.65}\left(\mathrm{PO}_{4}\right)_{2}: 0.3 \mathrm{~Tb}^{3+}, 0.05 \mathrm{Eu}^{3+}$ by monitoring the emission of $\mathrm{Tb}^{3+}$ at $546 \mathrm{~nm}$ is almost identical to that of $\mathrm{Na}_{3} \mathrm{~Tb}\left(\mathrm{PO}_{4}\right)_{2}$ (Fig. 6a) within the experimental error. The PLE band/line of $\mathrm{Eu}^{3+}$ is undetectable, implying that $\mathrm{Eu}^{3+}$ cannot transfer energy to $\mathrm{Tb}^{3+}$. The PLE spectrum recorded at the $620 \mathrm{~nm}$ of $\mathrm{Eu}^{3+}$ emission is dominated by $\mathrm{Tb}^{3+}$ bands/lines, which are similar to that of monitoring the $\mathrm{Tb}^{3+}$-emission, but shows large difference with that of $\mathrm{Eu}^{3+}$ (Fig. 6b). Only several f-f transition lines of $\mathrm{Eu}^{3+}$ are evidently observed (marked by stars in Fig. 6c). The presence of $\mathrm{Tb}^{3+}$-related PLE bands/lines in the PLE spectrum of $\mathrm{Eu}^{3+}$ emission clearly indicates the occurrence of energy transfer from $\mathrm{Tb}^{3+}$ to $\mathrm{Eu}^{3+}$. Upon $394 \mathrm{~nm}$ excitation $\left({ }^{7} \mathrm{~F}_{0} \rightarrow{ }^{5} \mathrm{~L}_{6}\right.$ of $\left.\mathrm{Eu}^{3+}\right)$, only emission from $\mathrm{Eu}^{3+}$ is observed, and the positions of all emission peaks are identical to those in Fig. $6 \mathrm{~b}$ of $\mathrm{Na}_{3}$ $\mathrm{Eu}\left(\mathrm{PO}_{4}\right)_{2}$. Excited at $378 \mathrm{~nm} \mathrm{UV}$ irradiation $\left({ }^{7} \mathrm{~F}_{6} \rightarrow{ }^{5} \mathrm{G}_{6}\right.$ of $\left.\mathrm{Tb}^{3+}\right)$, the characteristic sharp emissions from both $\mathrm{Eu}^{3+}$ and $\mathrm{Tb}^{3+}$ can be detected, confirming that $\mathrm{Tb}^{3+}$ can partially transfer excitation energy to $\mathrm{Eu}^{3+}$ via its absorption of $4 \mathrm{f}$ state. Therefore, the relative intensities of these two emissions can be varied by adjusting the concentrations of the two activators through the principle of energy transfer.
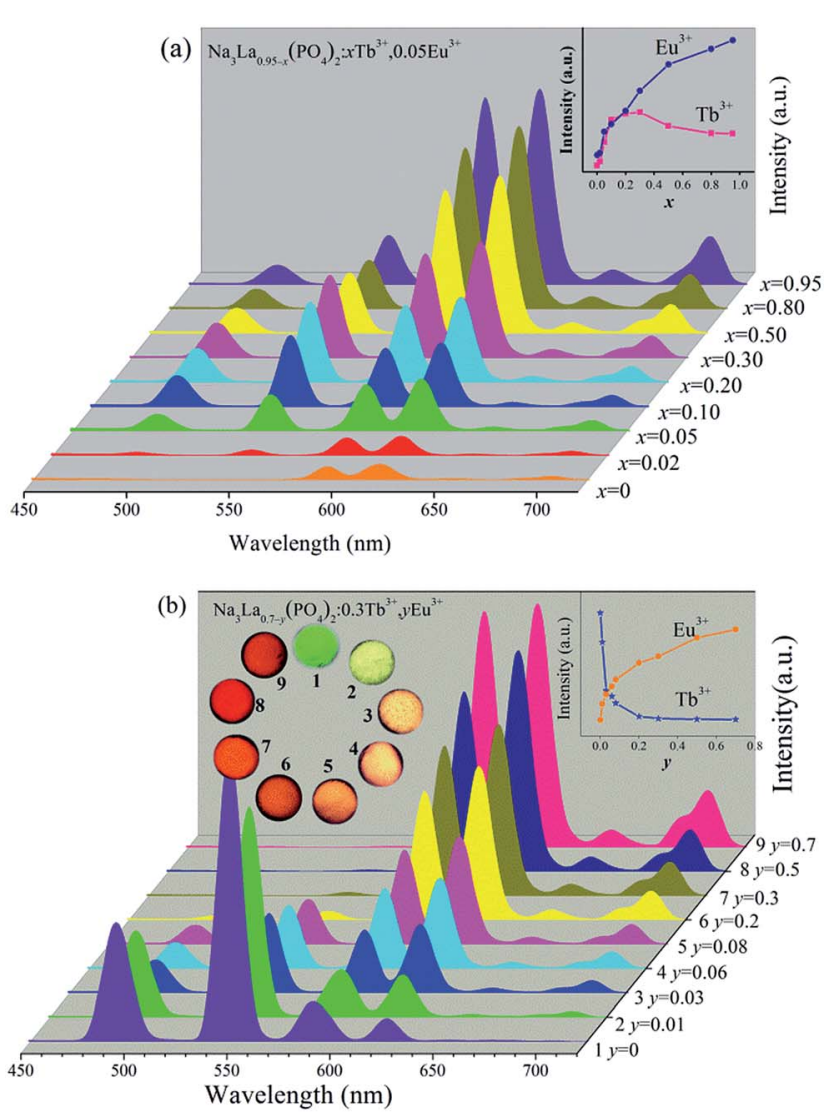

Fig. $7 \mathrm{PL}$ spectra $\left(\lambda_{\text {ex }}=378 \mathrm{~nm}\right)$ of $\mathrm{Na}_{3} \mathrm{La}_{0.95-x}\left(\mathrm{PO}_{4}\right)_{2}: x \mathrm{~Tb}^{3+}, 0.05 \mathrm{Eu}^{3+}$ $(x=0-0.95, a)$ and Na $\mathrm{La}_{0.7-y}\left(\mathrm{PO}_{4}\right)_{2}: 0.3 \mathrm{~Tb}^{3+}, y \mathrm{Eu}^{3+}(y=0-0.7, b)$ phosphors together with their digital photographs under a $365 \mathrm{~nm}$ UV lamp. 
Fig. 7 illustrates the variations of PL spectra and corresponding intensities of $\mathrm{Na}_{3} \mathrm{La}_{0.95-x}\left(\mathrm{PO}_{4}\right)_{2}: x \mathrm{~Tb}^{3+}, 0.05 \mathrm{Eu}^{3+}$ and $\mathrm{Na}_{3} \mathrm{La}_{0.7-y}\left(\mathrm{PO}_{4}\right)_{2}: 0.3 \mathrm{~Tb}^{3+}, y \mathrm{Eu}^{3+}$ phosphors. The emission profile of all the $\mathrm{Tb}^{3+} / \mathrm{Eu}^{3+}$ codoped samples contain the characteristic sharp emission peaks of both $\mathrm{Tb}^{3+}$ and $\mathrm{Eu}^{3+}$ under excitation at $378 \mathrm{~nm}$. The increasing concentrations of the $\mathrm{Eu}^{3+}$ or $\mathrm{Tb}^{3+}$ ions bring no obvious alteration in the intensity ratio of $\left({ }^{5} \mathrm{D}_{0} \rightarrow{ }^{7} \mathrm{~F}_{2}\right) /$ $\left({ }^{5} \mathrm{D}_{0} \rightarrow{ }^{7} \mathrm{~F}_{1}\right)$, indicating that the degree of the local symmetry around $\mathrm{Eu}^{3+}$ ions keeps constant. As shown in Fig. 7a, the PL intensities of $\mathrm{Eu}^{3+}$ at $620 \mathrm{~nm}$ increase systematically with increasing the $\mathrm{Tb}^{3+}$ concentration $(x)$, because the increase of $\mathrm{Tb}^{3+}$ concentration results in more sensitizers transferring the energy to $\mathrm{Eu}^{3+}$ ions. Meanwhile, the $\mathrm{Tb}^{3+}$ green emission intensity reaches its maximum at $x=0.3$, and then decreases due to the concentration quenching effect with further increasing the $\mathrm{Tb}^{3+}$ concentration $(x)$. The inset of Fig. $7 \mathrm{a}$ depicts the dependences of the PL intensities $\left(\left({ }^{5} \mathrm{D}_{4} \rightarrow{ }^{7} \mathrm{~F}_{5}\right.\right.$ transition of $\mathrm{Tb}^{3+} ;{ }^{5} \mathrm{D}_{0} \rightarrow{ }^{7} \mathrm{~F}_{2}$ transition of $\left.\mathrm{Eu}^{3+} ; \lambda_{\mathrm{ex}}=378 \mathrm{~nm}\right)$ ) on the $\mathrm{Tb}^{3+}$ concentration $(y)$. The $\mathrm{Eu}^{3+} \mathrm{PL}$ intensity is enhanced about 11 times by codoping with $\mathrm{Tb}^{3+}$. In Fig. 7b, the PL intensity of $\mathrm{Tb}^{3+}$ decreases monotonously with the increase of $\mathrm{Eu}^{3+}$ concentration from $y=0$ to 0.7 , while the $\mathrm{Eu}^{3+} \mathrm{PL}$ intensity increases to a maximum at $y=0.7$. This observation indicates that the energy transfer from $\mathrm{Tb}^{3+}$ to $\mathrm{Eu}^{3+}$ ions can occur in current excitation condition in $\mathrm{Tb}^{3+} / \mathrm{Eu}^{3+}$ codoped $\mathrm{Na}_{3} \mathrm{La}\left(\mathrm{PO}_{4}\right)_{2}$ phosphor. Therefore, the relative intensities of these two emissions can be varied by adjusting the concentrations of the two activators through the principle of energy transfer to realize the tunable emission color. The digital emission color photos were depicted in the inset of Fig. 7b, clearly indicating that the emission color can be tuned from green to reddish orange with increasing the $\mathrm{Eu}^{3+}$ concentration $(y)$.

\section{Decay curves and energy transfer mechanism}

It has been witnessed that an efficient energy transfer from $\mathrm{Tb}^{3+}$ to $\mathrm{Eu}^{3+}$ occurs in $\mathrm{Na}_{3} \mathrm{La}\left(\mathrm{PO}_{4}\right)_{2}$ host. In order to further investigate the energy transfer between $\mathrm{Tb}^{3+}$ and $\mathrm{Eu}^{3+}$ in $\mathrm{Na}_{3} \mathrm{La}\left(\mathrm{PO}_{4}\right)_{2}$, luminescent decay curves of $\mathrm{Tb}^{3+}$ emission and $\mathrm{Eu}^{3+}$ emission in $\mathrm{Na}_{3} \mathrm{La}_{0.7-y}\left(\mathrm{PO}_{4}\right)_{2}: 0.3 \mathrm{~Tb}^{3+}, y \mathrm{Eu}^{3+}(y=0-0.7)$ samples have been measured. The decay curves monitored at $546 \mathrm{~nm}\left(\mathrm{~Tb}^{3+}{ }^{3} \mathrm{D}_{4} \rightarrow\right.$ ${ }^{7} \mathrm{~F}_{5}$ transition) and $620 \mathrm{~nm}\left(\mathrm{Eu}^{3+5} \mathrm{D}_{0} \rightarrow{ }^{7} \mathrm{~F}_{5}\right.$ transition) with excitation of $378 \mathrm{~nm}$ irradiation are presented in Fig. 8a and b, respectively.

It is found that the decay curves of $\mathrm{Tb}^{3+}$ emission cannot be fitted in terms of a single-exponential function, but can be well fitted by a double-exponential function:

$$
I=A_{1} \exp \left(-t / \tau_{1}\right)+A_{2} \exp \left(-t / \tau_{2}\right)
$$

where $I$ is the luminous intensity at time $t ; A_{1}$ and $A_{2}$ are the fitting parameters; and $\tau_{1}$ and $\tau_{2}$ are rapid and slow lifetimes for exponential components, respectively. The decay process of these samples is characterized by an effective lifetime $\tau$, which can be calculated using eqn (2) as follows

$$
\tau=\left(A_{1} \tau_{1}^{2}+A_{2} \tau_{2}^{2}\right) /\left(A_{1} \tau_{1}+A_{2} \tau_{2}\right)
$$
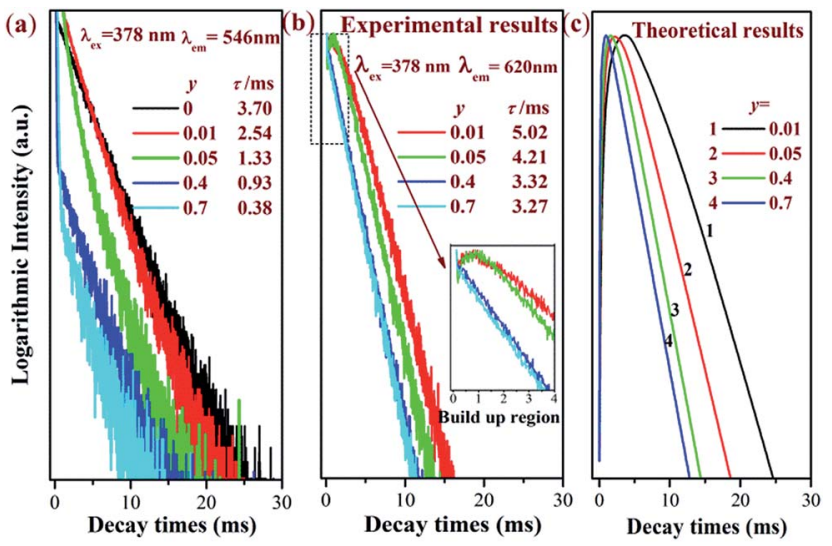

Fig. 8 Luminescence decay curves of $\mathrm{Tb}^{3+} 546 \mathrm{~nm}$ emission $\left({ }^{5} \mathrm{D}_{4} \rightarrow\right.$ $\left.{ }^{7} F_{5}\right)(a), E u^{3+} 620 \mathrm{~nm}$ emission $\left({ }^{5} D_{0} \rightarrow{ }^{7} F_{5}\right)(b)$ and the corresponding simulation curves (c).

The values of $\tau_{\mathrm{Tb}}$ are calculated to be 3.70, 2.54, 1.33, 0.93 and $0.38 \mathrm{~ms}$ for $\mathrm{Na}_{3} \mathrm{La}_{0.7-y}\left(\mathrm{PO}_{4}\right)_{2}: 0.3 \mathrm{~Tb}^{3+}, y \mathrm{Eu}^{3+}$ phosphors with $y=0,0.01,0.05,0.4$ and 0.7. As shown in Fig. 9, the effective lifetime of $\mathrm{Tb}^{3+}$ ions decreases with the increase of $\mathrm{Eu}^{3+}$ due to the $\mathrm{ET}_{\mathrm{Tb} \rightarrow \mathrm{Eu}}$ process.

For the $\mathrm{ET}_{\mathrm{Tb} \rightarrow \mathrm{Eu}}$ process, the transfer probability $\left(P_{\mathrm{Tb} \rightarrow \mathrm{Eu}}\right)$ can be expressed by eqn $(3)^{42}$

$$
P_{\mathrm{Tb} \rightarrow \mathrm{Eu}}=1 / \tau-1 / \tau_{0}
$$

where $P_{\mathrm{Tb} \rightarrow \mathrm{Eu}}$ is the energy transfer probability and $\tau$ and $\tau_{0}$ are the lifetimes for $\mathrm{Tb}^{3+}$ with and without the $\mathrm{Eu}^{3+}$ ions, respectively. In addition, the energy transfer efficiency $\left(\eta_{\mathrm{Tb} \rightarrow \mathrm{Eu}}\right)$ can be evaluated using eqn (4),

$$
\eta_{\mathrm{Tb} \rightarrow \mathrm{Eu}}=1-\tau / \tau_{0}
$$

The values of $P_{\mathrm{Tb} \rightarrow \mathrm{Eu}}$ and $\eta_{\mathrm{Tb} \rightarrow \mathrm{Eu}}$ are calculated and are also shown in Fig. 9. Both the values of $P_{\mathrm{Tb} \rightarrow \mathrm{Eu}}$ and $\eta_{\mathrm{Tb} \rightarrow \mathrm{Eu}}$ increase obviously with increasing the $\mathrm{Eu}^{3+}$ concentration $(y)$, indicating that the energy-transfer process become more efficient with high $\mathrm{Eu}^{3+}$ ion concentration.

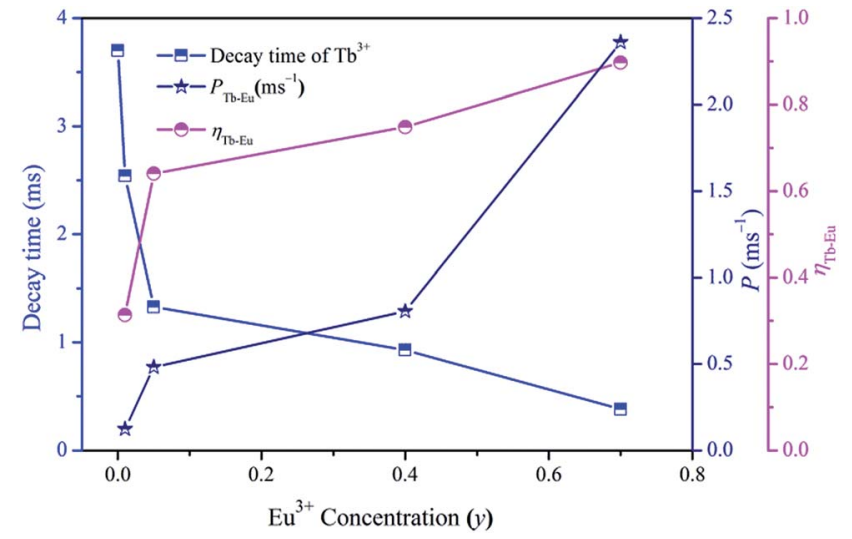

Fig. 9 Dependence of $\mathrm{Tb}^{3+}$ decay time, $P_{\mathrm{Tb} \rightarrow \mathrm{Eu}}$ and $\eta_{\mathrm{Tb} \rightarrow \mathrm{Eu}}$ on $\mathrm{Eu}^{3+}$ concentration $(y)$ in $\mathrm{Na}_{3} \mathrm{La}_{0.7-y}\left(\mathrm{PO}_{4}\right)_{2}: 0.3 \mathrm{~Tb}^{3+}, y \mathrm{Eu}^{3+}$. 
Fig. $8 \mathrm{~b}$ illustrates the decay curves of $\mathrm{Eu}^{3+}$ emission. All the decay curves of $\mathrm{Eu}^{3+}$ emission could be well fitted into singly exponential equation

$$
I_{t}=I_{0} \exp (-t / \tau)
$$

where $I_{0}$ and $I_{t}$ are for the intensities of $\mathrm{Eu}^{3+}$ emission at time $t_{0}$ and $t$, respectively; $\tau$ denotes the lifetimes for $\mathrm{Eu}^{3+}$. The calculated values of $\tau_{\mathrm{Eu}}$ are 5.02, 4.21, 3.32 and $3.27 \mathrm{~ms}$ for $y=0.01$, $0.05,0.4$ and 0.7 in $\mathrm{Na}_{3} \mathrm{La}_{0.7-y}\left(\mathrm{PO}_{4}\right)_{2}: 0.3 \mathrm{~Tb}^{3+}, y \mathrm{Eu}^{3+}$ phosphors.

It is obvious that the $\mathrm{Eu}^{3+}$ decay curves recorded at the ${ }^{5} \mathrm{D}_{0} \rightarrow$ ${ }^{7} \mathrm{~F}_{5}$ transition $(620 \mathrm{~nm})$ exhibit a rising step. The fluorescence intensity increases with increasing time, then reaching a maximum, and finally decreases until the decay process completes. Therefore, there are two different processes for the emission of $\mathrm{Eu}^{3+}$ : decay process and build-up process. In the initial build-up process, the energy absorbed by the ${ }^{7} \mathrm{~F}_{6} \rightarrow{ }^{5} \mathrm{G}_{6}$ transition of $\mathrm{Tb}^{3+}$ ions is transferred to $\mathrm{Eu}^{3+}$ ions. This process is significantly influenced by the $\mathrm{Eu}^{3+}$ concentration. As shown in Fig. 8 b, with increasing the $\mathrm{Eu}^{3+}$ concentration $(y)$, the initial build-up process becomes faster and faster, suggesting that the $\mathrm{ET}_{\mathrm{Tb} \rightarrow \mathrm{Eu}}$ process becomes more efficient with higher $\mathrm{Eu}^{3+}$ concentration. ${ }^{43}$ When the $\mathrm{Na}_{3} \mathrm{La}_{0.7-y}\left(\mathrm{PO}_{4}\right)_{2}: 0.3 \mathrm{~Tb}^{3+}, y \mathrm{Eu}^{3+}$ samples are excited by $378 \mathrm{~nm}$ irradiation, the rate equations for the population densities in the ${ }^{5} \mathrm{D}_{4}$ level of $\mathrm{Tb}^{3+}$ and the ${ }^{5} \mathrm{D}_{0}$ of $\mathrm{Eu}^{3+}$ ion can be expressed as follows, ${ }^{44}$

$$
\begin{aligned}
& \mathrm{d} N_{\mathrm{Tb}} / \mathrm{d} t=-N_{\mathrm{Tb}} / \tau_{\mathrm{Tb}}-K_{\mathrm{Tb}-\mathrm{Eu}} N_{\mathrm{Tb}} \\
& \mathrm{d} N_{\mathrm{Eu}} / \mathrm{d} t=-N_{\mathrm{Eu}} / \tau_{\mathrm{Eu}}+K_{\mathrm{Tb}-\mathrm{Eu}} N_{\mathrm{Tb}}
\end{aligned}
$$

where the $N_{\mathrm{Tb}}$ and $N_{\mathrm{Eu}}$ are the population intensities of the ${ }^{5} \mathrm{D}_{4}$ level of $\mathrm{Tb}^{3+}$ and the ${ }^{5} \mathrm{D}_{0}$ of $\mathrm{Eu}^{3+}$, respectively. $K_{\mathrm{Tb}-\mathrm{Eu}}$ is the nonradiative energy transfer rate from the ${ }^{5} \mathrm{D}_{4}$ state of $\mathrm{Tb}^{3+}$ to ${ }^{5} \mathrm{D}_{0}$ of $\mathrm{Eu}^{3+}$. Then the fluorescence intensity $I(t)$ of $\mathrm{Eu}^{3+}$ ions at $620 \mathrm{~nm}$ excited at $378 \mathrm{~nm}$ irradiation can be given as following equation:

$$
\begin{aligned}
I(t) & =N_{\mathrm{Eu}}(t)=N_{\mathrm{Eu}} / \tau_{\mathrm{Eu}} \\
& =\frac{K_{\mathrm{Tb}-\mathrm{Eu}} N_{\mathrm{Tb}}}{1 / \tau_{\mathrm{Eu}}-1 / \tau_{\mathrm{Tb}}}\left[\exp \left(-\frac{t}{\tau_{\mathrm{Tb}}}\right)-\exp \left(-\frac{t}{\tau_{\mathrm{Eu}}}\right)\right]
\end{aligned}
$$

Using the measured values of $\tau_{\mathrm{Tb}}$ and $\tau_{\mathrm{Eu}}$, the simulation curves for $\mathrm{Na}_{3} \mathrm{La}_{0.7-y}\left(\mathrm{PO}_{4}\right)_{2}: 0.3 \mathrm{~Tb}^{3+}, y \mathrm{Eu}^{3+}$ samples are obtained as presented in Fig. 8c, which show two process for $\mathrm{Eu}^{3+}$ emission, being similar to the measured curves. That is to say, the theoretical results are consistent with the experimental observations.

In general, the energy transfer between the sensitizer and activator may take place via exchange interaction and multipolar interaction. The energy transfer mechanism can be determined using the following relationship: ${ }^{45}$

$$
\ln \left(I_{0} / I\right) \propto C \text { and } I_{\mathrm{S} 0} / I_{\mathrm{S}} \propto C^{\alpha / 3}
$$

in which $I_{\mathrm{So}}$ and $I_{\mathrm{S}}$ are the luminescence intensities of $\mathrm{Tb}^{3+}$ in the absence and presence of $\mathrm{Eu}^{3+}$, respectively; $C$ is the total concentration of $\mathrm{Tb}^{3+}$ and $\mathrm{Eu}^{3+} ; \ln \left(I_{\mathrm{SO}} / I_{\mathrm{S}}\right) \propto C$ is corresponding to the exchange interaction; $\alpha=6,8$, and 10 are dipole-dipole, dipole-quadrupole, and quadrupole-quadrupole interactions. The relationships are illustrated in Fig. 10a-d, respectively for $\mathrm{Na}_{3} \mathrm{La}_{0.7-y}\left(\mathrm{PO}_{4}\right)_{2}: 0.3 \mathrm{~Tb}^{3+}, y \mathrm{Eu}^{3+}$ phosphors. The linear behavior was observed only when $\alpha=6$, indicating that energy transfer from $\mathrm{Tb}^{3+}$ to $\mathrm{Eu}^{3+}$ in $\mathrm{Na}_{3} \mathrm{La}\left(\mathrm{PO}_{4}\right)_{2}$ host occurs via a dipole-dipole interaction.

The scheme of energy transfer from $\mathrm{Tb}^{3+}$ to $\mathrm{Eu}^{3+}$ in $\mathrm{Na}_{3}$ $\mathrm{La}\left(\mathrm{PO}_{4}\right)_{2}$ host is demonstrated in Fig. $11 . \mathrm{Tb}^{3+}$ ions absorb the energy from $378 \mathrm{~nm}$ irradiation and are excited from the ground state of $\left({ }^{7} \mathrm{~F}_{6}\right)$ to the excited states of ${ }^{5} \mathrm{D}_{J}(J=2,3,4)$. Some of the excited $\mathrm{Tb}^{3+}$ radiative transmit from ${ }^{5} \mathrm{D}_{3}$ to the ground state ${ }^{7} \mathrm{~F}_{6}$ directly with relatively weaker blue light emission of 415 and $437 \mathrm{~nm}$, and other excited $\mathrm{Tb}^{3+}$ relax to the lowest excited state ${ }^{5} \mathrm{D}_{4}$ through non-radiative transition, then radiative decay to the ground state $\left({ }^{7} \mathrm{~F}_{6}\right)$ with a strong green emission. When $\mathrm{Eu}^{3+}$ ions are codoped, part of the energy from ${ }^{5} \mathrm{D}_{4}$ to ${ }^{7} \mathrm{~F}_{J}$ transition of $\mathrm{Tb}^{3+}$ will be transferred to $\mathrm{Eu}^{3+}$ through cross-relaxation due the obvious overlap between the ${ }^{5} \mathrm{D}_{4} \rightarrow{ }^{7} \mathrm{~F}_{J}$ emission of $\mathrm{Tb}^{3+}$ and ${ }^{7} \mathrm{~F}_{0,1} \rightarrow{ }^{5} \mathrm{D}_{0,1,2}$ absorption of $\mathrm{Eu}^{3+}$, then relax to the ground state ${ }^{5} \mathrm{D}_{0}$ of $\mathrm{Eu}^{3+}$ and finally radiative decay to the ground state $\left({ }^{7} \mathrm{~F}_{0}\right)$ with an reddish orange emission. ${ }^{44}$

\section{CIE chromaticity coordinates of $\mathrm{Na}_{3} \mathrm{La}\left(\mathrm{PO}_{4}\right)_{2}: \mathrm{Tb}^{3+}, \mathrm{Eu}^{3+}$}

The CIE chromaticity coordinates $(X, Y)$ for $\mathrm{Na}_{3} \mathrm{La}_{0.7-y}(-$ $\left.\mathrm{PO}_{4}\right)_{2}: 0.3 \mathrm{~Tb}^{3+}, y \mathrm{Eu}^{3+}(y=0-0.7)$ samples were calculated in the case of $378 \mathrm{~nm}$ excitation and the results are shown in Fig. 12. The chromaticity coordinates of $\mathrm{Na}_{3} \mathrm{Eu}\left(\mathrm{PO}_{4}\right)_{2}$ phosphor is also presented. The CIE chromaticity coordinates $(X, Y)$ changes from point $1(0.2987,0.5695)$ to point $7(0.6203,0.3505)$ with the increase of $\mathrm{Eu}^{3+}$ concentration $(y)$. The as formed $\mathrm{Na}_{3} \mathrm{La}_{0.95-x}(-$ $\left.\mathrm{PO}_{4}\right)_{2}: x \mathrm{~Tb}^{3+}, 0.05 \mathrm{Eu}^{3+}(x=0-0.95)$ phosphors show typical reddish-orange luminescence. However, their CIE coordinates are too close to be distinguished from each other in a chromaticity diagram with the changes of the $\mathrm{Tb}^{3+}$ ion concentration, so they are not presented.
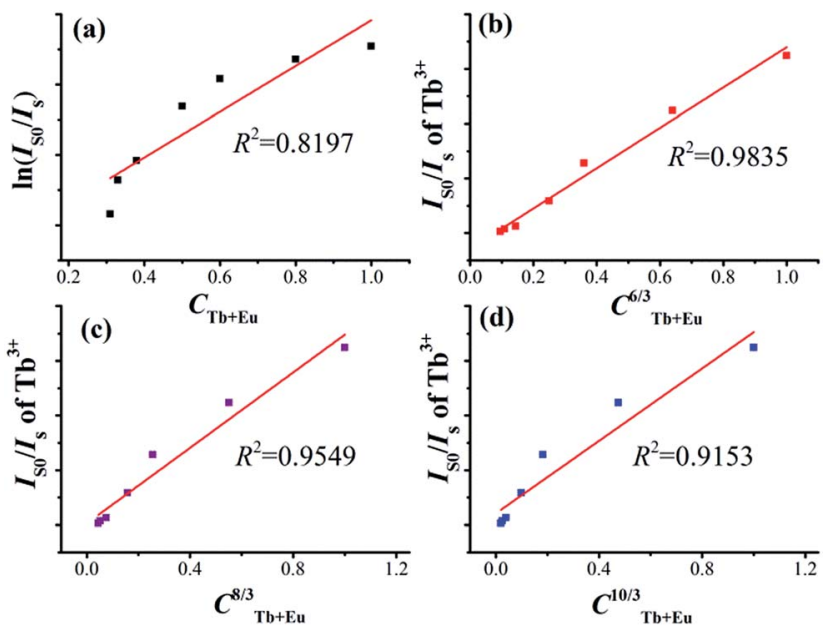

Fig. 10 Dependence of $\ln \left(/_{\mathrm{SO}} / /_{\mathrm{S}}\right)$ on $C_{\mathrm{Tb}+\mathrm{Eu}}(\mathrm{a})$ and the dependence of $I_{\mathrm{SO}} / I_{\mathrm{S}}$ on $\mathrm{C}_{\mathrm{Tb}+\mathrm{Eu}}{ }^{6 / 3}$ (b), $C_{\mathrm{Tb}+\mathrm{Eu}}{ }^{8 / 3}$ (c) and $C_{\mathrm{Tb}+\mathrm{Eu}}{ }^{10 / 3}$ (d). 


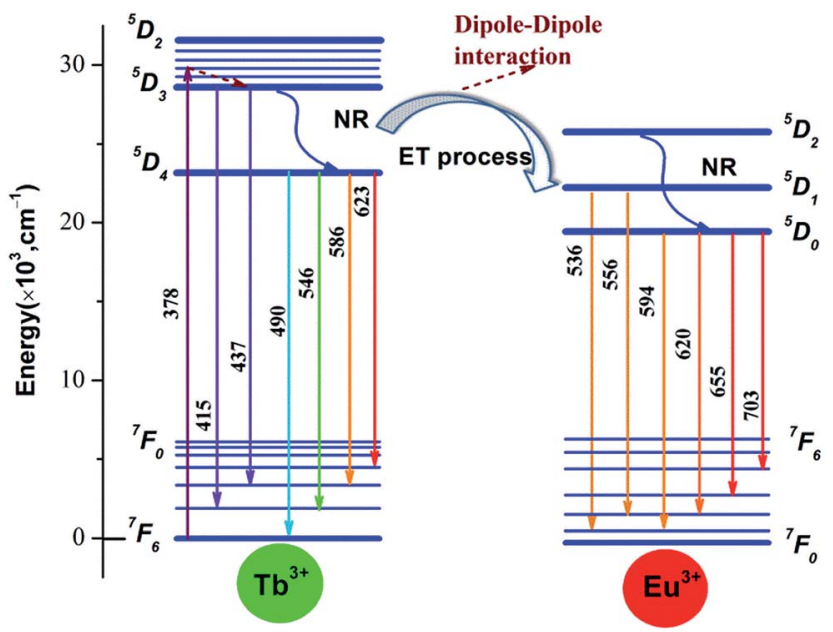

Fig. 11 Scheme of energy transfer from $\mathrm{Tb}^{3+}$ to $\mathrm{Eu}^{3+}$ in $\mathrm{Na}_{3} \mathrm{La}\left(\mathrm{PO}_{4}\right)_{2}$ host.

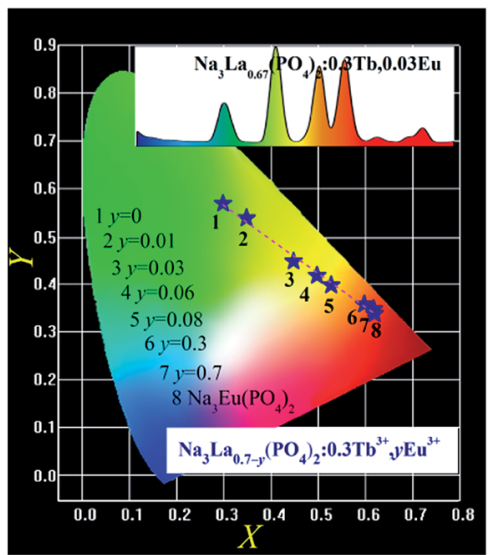

Fig. $12 \mathrm{CIE}$ chromaticity diagram of the selected $\mathrm{Na}_{3} \mathrm{La}_{0.7-y}(-$ $\left.\mathrm{PO}_{4}\right)_{2}: 0.3 \mathrm{~Tb}^{3+}, y \mathrm{Eu}^{3+}(y=0-0.7)$ and $\mathrm{Na}_{3} \mathrm{Eu}\left(\mathrm{PO}_{4}\right)_{2}$ phosphors under $378 \mathrm{~nm}$ UV irradiation excitation. The inset shows the PL spectrum of $\mathrm{Na}_{3} \mathrm{La}_{0.67}\left(\mathrm{PO}_{4}\right)_{2}: 0.3 \mathrm{~Tb}^{3+}, 0.03 \mathrm{Eu}^{3+}$ under $378 \mathrm{~nm}$ UV irradiation excitation.

The PL spectrum of $\mathrm{Na}_{3} \mathrm{La}_{0.67}\left(\mathrm{PO}_{4}\right)_{2}: 0.3 \mathrm{~Tb}^{3+}, 0.03 \mathrm{Eu}^{3+}$ phosphor shown as inset in Fig. 12 exhibits a green emission of the $\mathrm{Tb}^{3+}$ and the red emission of the $\mathrm{Eu}^{3+}$ ions. These emission lines of $\mathrm{Tb}^{3+}$ and $\mathrm{Eu}^{3+}$ cover the whole visible light region with tunable intensity, resulting in a color-tunable emission. Therefore, it can be expected to achieve color-tunable emission by regulating spectral composition induced by the energy transfer between $\mathrm{Tb}^{3+}$ and $\mathrm{Eu}^{3+}$ ions in the $\mathrm{Na}_{3} \mathrm{La}\left(\mathrm{PO}_{4}\right)_{2}$ host under NUV irradiation excitation. According to Grassman's Laws of additive color mixture, ${ }^{\mathbf{4 6 , 4 7}}$ the emission color of $\mathrm{Na}_{3}$ $\mathrm{La}\left(\mathrm{PO}_{4}\right)_{2}: \mathrm{Tb}^{3+}, \mathrm{Eu}^{3+}$ can be matched by a linear combination of the emission color of $\mathrm{Na}_{3} \mathrm{La}\left(\mathrm{PO}_{4}\right)_{2}: \mathrm{Tb}^{3+}$ and that of $\mathrm{Na}_{3}$ $\mathrm{La}\left(\mathrm{PO}_{4}\right)_{2}: \mathrm{Eu}^{3+}$. It is obvious that the coordinate $Y$ changes linearly with the coordinate $X$ as shown in Fig. 12. Plotting $y v s$. $x$, a straight line is obtained. The values of intercept, slope, and linear regression coefficient are $0.7782,-0.7037$, and 0.9902 respectively. The expression is shown as below:

$$
Y=0.7782-0.7037 X
$$

The above equation should mathematically demonstrate the range of chromaticity coordinates that we can obtain by adjusting the $\mathrm{Tb}^{3+}$ and $\mathrm{Eu}^{3+}$ concentrations. It is obvious that the chromaticity coordinates for the $\mathrm{Na}_{3} \mathrm{La}\left(\mathrm{PO}_{4}\right)_{2}: \mathrm{Tb}^{3+}, \mathrm{Eu}^{3+}$ phosphor falls on a line connecting the two chromaticity coordinates of $\mathrm{Na}_{3} \mathrm{La}\left(\mathrm{PO}_{4}\right)_{2}: \mathrm{Tb}^{3+}$ and $\mathrm{Na}_{3} \mathrm{La}\left(\mathrm{PO}_{4}\right)_{2}: \mathrm{Eu}^{3+}$, respectively. With increasing the $\mathrm{Eu}^{3+}$ concentration $(y)$, the chromaticity coordinate for $\mathrm{Na}_{3} \mathrm{La}_{0.7-y}\left(\mathrm{PO}_{4}\right)_{2}: 0.3 \mathrm{~Tb}^{3+}, y \mathrm{Eu}^{3+}$ phosphors move from the chromaticity point 1 of $\mathrm{Na}_{3} \mathrm{La}_{0.7}\left(\mathrm{PO}_{4}\right)_{2}: 0.3 \mathrm{~Tb}^{3+}$ toward point 8 of $\mathrm{Na}_{3} \mathrm{Eu}\left(\mathrm{PO}_{4}\right)_{2}$ along this straight line. The prepared $\mathrm{Na}_{3} \mathrm{La}\left(\mathrm{PO}_{4}\right)_{2}: \mathrm{Tb}^{3+}, \mathrm{Eu}^{3+}$ phosphor exhibits efficient tunable emission in the visible-light region upon excitation with NUV irradiation, and might find potential applications in multicolor displays and other optoelectronic devices.

\section{Conclusions}

In a conclusion, a series of $\mathrm{Tb}^{3+}$ and/or $\mathrm{Eu}^{3+}$ doped $\mathrm{Na}_{3} \mathrm{La}\left(\mathrm{PO}_{4}\right)_{2}$ phosphors have been successfully synthesized and their luminescence properties have been investigated in detail. The glaserite-like orthorhombic structure provides the $\mathrm{Na}_{3} \mathrm{La}\left(\mathrm{PO}_{4}\right)_{2}$ host the possibility of doping with $\mathrm{Tb}^{3+}$ or $\mathrm{Eu}^{3+}$ ions without substantial luminescence quenching. $\mathrm{Tb}^{3+}$ can efficiently sensitize $\mathrm{Eu}^{3+}$ emission under NUV excitation. The energy transfer mechanism $\left(\mathrm{Tb}^{3+} \rightarrow \mathrm{Eu}^{3+}\right.$ ) was demonstrated to be dominated by a dipole-dipole interaction. The luminescence decay properties of $\mathrm{Eu}^{3+}$ in $\mathrm{Na}_{3} \mathrm{La}\left(\mathrm{PO}_{4}\right)_{2}: \mathrm{Tb}^{3+}, \mathrm{Eu}^{3+}$ samples under ${ }^{7} \mathrm{~F}_{6}-{ }^{5} \mathrm{G}_{6}$ excitation $(378 \mathrm{~nm})$ within $\mathrm{Tb}^{3+}$ ions were simulated with the energy transfer theory. The emission color of $\mathrm{Na}_{3} \mathrm{La}_{0.7-y}\left(\mathrm{PO}_{4}\right)_{2}: 0.3 \mathrm{~Tb}^{3+}, y \mathrm{Eu}^{3+}$ phosphors can be tunable from green through yellow and red region by adjusting the $\mathrm{Eu}^{3+}$ concentration. These results indicate that the as-synthesized phosphors may find potential applications as a color-tunable emitting material in solid state lighting.

\section{Acknowledgements}

This research was financially supported by "the Fundamental Research Funds for the Central Universities”, South-Central University for Nationalities (CZY15002).

\section{Notes and references}

1 S. V. Eliseeva and J. C. G. Bünzli, New J. Chem., 2011, 35, 1165-1176.

2 T. Jüstel, H. Nikol and C. Ronda, Angew. Chem., Int. Ed., 1998, 37, 3084-3103.

3 C. Li, J. Yang, P. Yang, H. Lian and J. Lin, Chem. Mater., 2008, 20, 4317-4326.

4 T. Katsumata, K. Sasajima, T. Nabae, S. Komuro and T. Morikawa, J. Am. Ceram. Soc., 1998, 81, 413-416.

5 W.-R. Liu, C.-H. Huang, C.-W. Yeh, J.-C. Tsai, Y.-C. Chiu, Y.-T. Yeh and R.-S. Liu, Inorg. Chem., 2012, 51, 9636-9641.

6 R. P. Rao, J. Lumin., 2005, 113, 271-278. 
7 T. Aitasalo, M. Guzik, W. Szuszkiewicz, J. Hölsä, B. Keller and J. Legendziewicz, J. Alloys Compd., 2004, 380, 405-412.

8 M. Kloss, B. Finke, L. Schwarz and D. Haberland, J. Lumin., 1997, 72-74, 684-686.

9 J. Matt Farmer, L. A. Boatner, B. C. Chakoumakos, C. J. Rawn and J. Richardson, J. Alloys Compd., 2016, 655, 253-265.

10 M. Guzik, T. Aitasalo, W. Szuszkiewicz, J. Hölsä, B. Keller and J. Legendziewicz, J. Alloys Compd., 2004, 380, 368-375.

$11 \mathrm{~J}$. Chékir-Mzali, K. Horchani-Naifer and M. Férid, Superlattices Microstruct., 2015, 85, 445-453.

12 H. Liang, Z. Tian, H. Lin, M. Xie, G. Zhang, P. Dorenbos and Q. Su, Opt. Mater., 2011, 33, 618-622.

13 A. Matraszek, P. Godlewska, L. Macalik, K. Hermanowicz, J. Hanuza and I. Szczygieł, J. Alloys Compd., 2015, 619, 275283.

14 F. W. Kang, Y. Zhang and M. Y. Peng, Inorg. Chem., 2015, 54, 1462-1473.

15 F. Kang, Y. Zhang, L. Wondraczek, J. Zhu, X. Yang and M. Peng, J. Mater. Chem. C, 2014, 2, 9850-9857.

16 F. Kang, H. Zhang, L. Wondraczek, X. Yang, Y. Zhang, D. Lei and M. Peng, Chem. Mater., 2016, 28, 2692-2703.

17 C.-H. Huang, P.-J. Wu, J.-F. Lee and T.-M. Chen, J. Mater. Chem., 2011, 21, 10489-10495.

18 M. Shang, D. Geng, D. Yang, X. Kang, Y. Zhang and J. Lin, Inorg. Chem., 2013, 52, 3102-3112.

19 K. Li, M. Shang, H. Lian and J. Lin, J. Mater. Chem. C, 2016, 4, 5507-5530.

20 F. Kang, Y. Zhang and M. Peng, Inorg. Chem., 2015, 54, 14621473.

21 L. Li, Y. Liu, R. Li, Z. Leng and S. Gan, $R S C A d v .$, 2015, 5, 7049-7057.

22 Q. Dan and T. Wanjun, Ceram. Int., 2016, 42, 1538-1544.

23 K. Li, S. Liang, M. Shang, H. Lian and J. Lin, Inorg. Chem., 2016, 55, 7593-7604.

24 J. Zhou and Z. Xia, J. Mater. Chem. C, 2014, 2, 6978-6984.

25 A. C. Larson and R. B. Von Dreele, Generalized Structure Analysis System (GSAS), Los Alamos National Laboratory, Los Alamos, NM, 1994, pp. 86-748.

26 R. D. Shannon, Acta Crystallogr., Sect. A: Cryst. Phys., Diffr., Theor. Gen. Crystallogr., 1976, 32, 751-767.
27 R. Salmon, C. Parent, M. Vlasse and G. Le Flem, Mater. Res. Bull., 1978, 13, 439-444.

28 W. D. Kingery, H. K. Bowen and D. R. Uhlmann, Introduction to Ceramics, Wiley, New York, 1976.

29 W. Liu, D. Wang, Y. Wang, J. Zhang and H. Tao, J. Am. Ceram. Soc., 2013, 96, 2257-2263.

30 G. Ju, Y. Hu, L. Chen, X. Wang, Z. Mu, H. Wu and F. Kang, J. Alloys Compd., 2011, 509, 5655-5659.

31 C. M. Liu, D. J. Hou, J. Yan, L. Zhou, X. J. Kuang, H. B. Liang, Y. Huang, B. B. Zhang and Y. Tao, J. Phys. Chem. C, 2014, 118, 3220-3229.

32 X. Li, Y. Zhang, D. Geng, J. Lian, G. Zhang, Z. Hou and J. Lin, J. Mater. Chem. C, 2014, 2, 9924-9933.

33 G. Blasse and B. C. Grabmaier, Luminescent Materials, Springer, Berlin, 1994.

34 P. Gupta, A. K. Bedyal, V. Kumar, Y. Khajuria, V. Kumar, E. Coetsee-Hugo, O. M. Ntwaeaborwa and H. C. Swart, Opt. Mater., 2014, 36, 996-1001.

35 B. R. Judd, Phys. Rev., 1962, 127, 750-761.

36 G. S. Ofelt, J. Chem. Phys., 1962, 37, 511-520.

37 G. R. Dillip, S. J. Dhoble, L. Manoj, C. M. Reddy and B. D. P. Raju, J. Lumin., 2012, 132, 3072-3076.

38 J. Legendziewicz, M. Guzik and J. Cybińska, Opt. Mater., 2009, 31, 567-574.

39 A. Pelczarska, A. Watras, P. Godlewska, E. Radominska, L. Macalik, I. Szczygieł, J. Hanuzaab and P. J. Deren, New J. Chem., 2015, 39, 8474-8483.

40 S. Chen, Y. Wang, J. Zhang, L. Zhao, Q. Wang and L. Han, J. Lumin., 2014, 150, 46-49.

41 T. Jiang, X. Yu, X. Xu, H. Yu, D. Zhou and J. Qiu, Opt. Mater., 2014, 36, 611-615.

42 Y. C. Li, Y. H. Chang, Y. S. Chang, Y. J. Lin and C. H. Laing, J. Phys. Chem. C, 2007, 111, 10682-10688.

43 J. Zhong, H. Liang, Q. Su, J. Zhou, Y. Huang, Z. Gao, Y. Tao and J. Wang, Appl. Phys. B, 2010, 98, 139-147.

44 F. Xie, J. Li, Z. Dong, D. Wen, J. Shi, J. Yan and M. Wu, RSC Adv. , 2015, 5, 59830-59836.

45 R. Reisfeld, E. Greenberg, R. Velapoldi and B. Barnett, J. Chem. Phys., 1972, 56, 1698-1705.

46 H. Grassman, Philos. Mag., 1854, 7, 254-264.

47 W. Tang and Z. Zhang, J. Mater. Chem. C, 2015, 3, 5339-5346. 